\title{
The Professionalisation of Non-Denominational Religious Education in England: politics, organisation and knowledge
}

\author{
Stephen G. Parker, ${ }^{* 1}$ Rob Freathy, ${ }^{* *}$ and Jonathan Doney** \\ * Institute of Education, University of Worcester and **Graduate School of Education, \\ University of Exeter
}

\begin{abstract}
In response to contemporary concerns, and using neglected primary sources, this article explores the professionalisation of teachers of Religious Education (RI/RE) in nondenominational, state-maintained schools in England. It does so from the launch of Religion in Education (1934) and the Institute for Christian Education at Home and Abroad (1935) to the founding of the Religious Education Council of England and Wales (1973) and the British Journal of Religious Education (1978). Professionalisation is defined as a collective historical process in terms of three inter-related concepts: (1) professional self-organisation and professional politics, (2) professional knowledge, and (3) initial and continuing professional development. The article sketches the history of non-denominational religious education prior to the focus period, to contextualise the emergence of the professionalising processes under scrutiny. Professional self-organisation and professional politics are explored by reconstructing the origins and history of the Institute of Christian Education at Home and Abroad, which became the principal body offering professional development provision for $\mathrm{RI} / \mathrm{RE}$ teachers for some fifty years. Professional knowledge is discussed in relation to the content of Religion in Education which was oriented around Christian Idealism and interdenominational networking. Changes in journal name in the 1960s and 1970s reflected uncertainties about the orientation of the subject and shifts in understanding over the nature and character of professional knowledge. The article also explores a particular case of resistance, in the late 1960s, to the prevailing consensus surrounding the nature and purpose of RI/RE, and the representativeness and authority of the pre-eminent professional body of the time. In conclusion, the article examines some implications which may be drawn from this history for the prospects and problems of the professionalisation of RE today.
\end{abstract}

Keywords: Religious Education, professionalisation, professional self-organisation, professional politics, professional knowledge

\footnotetext{
${ }^{1}$ Corresponding author: s.parker@worc.ac.uk
} 


\section{Part One: Introduction}

\section{Rationale}

In current UK research on Religious Education (RE), there are no published studies, other than our own (Freathy et al 2014; Freathy et al 2016), focusing specifically upon 'professionalisation' as defined as the historical and institutional processes by which teachers of RE, as a collective occupational body, assumed their specific professional shape and characteristics over time (Horn 2016). Professionalisation differs from three other related concepts. 'Professionalism' refers to the structural and collective characteristics of teachers of RE as professionals at any given point in time (Horn 2016). 'Professionality' refers to the professional characteristics, skills and competencies that a professional teacher must acquire. 'Individual professionalisation' describes how these professional traits and abilities are acquired in individual learning processes, shaped by teacher training as well as by personal and other contextual factors (Freathy et al 2016). This distinction is important because the principle concern of this article is the collective, institutional and historical ‘professionalisation’ of teachers of RE.

Most recent UK studies on RE teachers have focused on 'individual professionalisation', predominantly individual teachers' and trainee teachers' conceptions of 'professionality', with reference to their personal and professional life histories, gender and cultural identities, and faith-perspectives (Bryan \& Revell 2011; Everington et al 2011; Everington 2014, 2015; Everington \& Sikes 2001; Sikes \& Everington 2003, 2004). A smaller body of work has focused on the contribution of research in RE teacher professional development (Baumfield 2010; Stern 2014) and philosophical conceptions of 'a good RE teacher' (Orchard \& Whately 2013). Alongside related perennial problems surrounding the scope, nature and purpose of RE in English schools (Freathy \& Parker 2015), the enduring significance of the 'professionalism' and ‘professionality' of RE teachers can be evidenced by:

(1) the historical shortage of specialist teachers and advisors, and insufficiency of initial and in-service teacher education (Copley 2008);

(2) recent research findings concerning the professional standing of RE teachers and teaching (Conroy et al 2013);

(3) contemporary evidence about the inadequate provision of suitably qualified RE teachers with appropriate levels of subject knowledge (APPG 2013; REC 2013); 
(4) concerns over the quality of RE teachers and teaching (OFSTED 2013); and

(5) a range of practical initiatives by some of the subject's stakeholders to increase the recruitment, improve the training, and recognise the success of RE teachers (Department for Education 2015; NATRE/REC 2013; Teach:RE 2015).

Yet RE teacher 'professionalism', 'professionality' and 'individual professionalisation' have not been considered in the context of the institutional and collective processes of professionalisation in which they are embedded (Freathy et al 2016), and which can only be illuminated by detailed and systematic historical research (Freathy \& Parker 2010; Freathy et al 2015).

\section{Focus of study}

This article begins to address this lacuna in knowledge by examining the history of the professionalisation of teachers of RE in non-denominational, state-maintained schools in England. It begins from the launch of Religion in Education (1934) and the Institute for Christian Education at Home and Abroad (1935) and covers the period up to the founding of the Religious Education Council of England and Wales (1973) and the British Journal of Religious Education (1978). However, it is necessary to clarify what we mean by RE. In the 1944 Education Act, religious education referred to the combination of Collective Worship and the curriculum subject, called Religious Instruction (RI). In practice, however, the curriculum subject was known by various names, for example, Religious Knowledge, Scripture and Divinity, and from the 1960s, an increasing number of writers used the term Religious Education. This practice was formalised by the 1988 Education Reform Act, which used Religious Education (RE) to refer to the classroom subject only. In this article, the term religious education, in the lower case, encompasses Religious Instruction, Collective Worship and other religious elements of schooling, while the curriculum subject alone will be referred to as RI, RE or RI/RE, all in the upper case. Each term is used with sensitivity to its particular historical context and whether it is important to make a distinction between them.

Although our primary research interest is the professionalisation of those who taught RI/RE in primary and secondary schools, the complex and significant connections between this subject and other curricular elements (e.g. Collective Worship), cross-curricular themes (e.g. spiritual and moral development), and the (religious) ethos and character of schools will be recognised throughout. In primary schools, particularly in the earlier stages of our focus 
period, RI/RE was rarely conceived as a discrete curriculum subject disconnected from religious education more broadly defined, and most RI/RE teachers had not received an initial, specialized academic and/or professional education in or relating to RI/RE. Predominantly, RI/RE teaching was undertaken by generalist teachers or specialists in other curriculum subjects. Consequently, a better description of our research interest is the professionalisation of those who taught the curriculum subject of RI/RE in primary and secondary schools, only insofar as professionalising processes pertained to that subject and cognate dimensions of the teachers' work (i.e. religious education), and not to the professionalisation of these teachers in the capacity of teachers. The exceptional legislative framework governing RI/RE, the relationships between teachers of RI/RE and other stakeholders (e.g. the churches), and the particular ontological and epistemological questions that arise concerning the subject's curriculum and pedagogy (Freathy et al 2016) position teachers of RI/RE as a special case. This justifies our decision to focus on this occupational group specifically. Next, we explain our conceptualisation of 'professionalisation'.

\section{Conceptualising professionalisation}

A survey of the recent literature on professionalisation has revealed a number of qualities which distinguish professions in general from other forms of occupation (Goodlad 1984; McClelland 1991; Freidson 1994; Macdonald 1995; Evetts 2003; Shattock 2014). For example, professions:

(1) have membership-led organisations representing their professional interests, such as the conditions of service and special codes of conduct;

(2) require advanced (and prolonged) training and education associated with particular standards of competence which are subject to examination and qualification;

(3) require specialized, advanced and complex knowledge and expertise;

(4) play a substantial role in determining the knowledge, standards and expertise and the professional development provision in the areas they profess;

(5) are characterized by collegial occupational relationships and mutual support;

(6) are self-regulating, autonomous and committed to service;

(7) are entered into through a selective recruitment process, manifesting control over membership, license to practice and the service market; and

(8) enjoy high social prestige, high economic rewards and a clear occupational career pattern or ladder. 
Overall, these qualities relate to structural and collective characteristics developed within a collegial environment and governed organisationally (i.e. professionalism). Their realisation is contingent upon a positive process of professionalisation (although it is accepted that professionalism can be eroded as well as constructed, and that professionalisation is not inevitable). Accordingly, following Freathy et al (2016), this article defines the professionalisation of teachers of RE as a historical process in terms of three inter-related concepts (see Table 1).

Table 1: Conceptual framework for the professionalisation of RE

\begin{tabular}{|c|c|}
\hline Concept & Definition \\
\hline $\begin{array}{c}\text { Professional self-organisation } \\
\text { and professional politics } \\
\text { (including legislation and the } \\
\text { role of faith communities) }\end{array}$ & $\begin{array}{c}\text { The professional self-organisation of teachers of RE } \\
\text { including professional associations (e.g. institutions, } \\
\text { organisations, groups and networks), legislation } \\
\text { concerning RE teachers and teacher training, and the } \\
\text { professional politics of other collective actors like faith } \\
\text { communities. }\end{array}$ \\
\hline Professional knowledge & $\begin{array}{c}\text { The body of specialized knowledge associated with the } \\
\text { professionalisation of RE teachers. }\end{array}$ \\
\hline $\begin{array}{c}\text { Initial and continuing } \\
\text { professional development (i.e. } \\
\text { specialized and advanced } \\
\text { academic education) }\end{array}$ & $\begin{array}{c}\text { The institutional structure, qualifications framework and } \\
\text { official curriculum of initial specialized and advanced } \\
\text { training of RE teachers as it is undertaken by universities, } \\
\text { higher education institutions and other providers including } \\
\text { those with(out) religious affiliations. }\end{array}$ \\
\hline
\end{tabular}

Furthermore, recognizing the complexity of the second of these concepts in particular, and building on the German COACTIV-model of teacher-professionality (Kunter et al 2011), Freathy et al (2014: 229) sub-divide professional knowledge in RE into a number of overlapping constituent elements (see Table 2).

Table 2. Constituent elements of professional knowledge in RE

\begin{tabular}{|c|c|}
\hline Type of Knowledge & Definition \\
\hline Subject-specific content & $\begin{array}{c}\text { Subject-specific content knowledge, that is, knowledge and } \\
\text { skills appropriated from the academic study of religion(s) } \\
\text { and most frequently derived from Theology, Religious } \\
\text { Studies and cognate disciplines. }\end{array}$ \\
\hline $\begin{array}{c}\text { Subject-specific } \\
\text { pedagogical methods }\end{array}$ & $\begin{array}{c}\text { Knowledge of subject-specific pedagogical methods, } \\
\text { including the principles and procedures of teaching, }\end{array}$ \\
\hline
\end{tabular}




\begin{tabular}{|c|c|}
\hline & learning and assessing in RE. \\
\hline Orientative & $\begin{array}{c}\text { Orientative knowledge pertaining to the ontological and } \\
\text { epistemological foundations and the aims and purposes } \\
\text { (including those of a theological and/or religious nature) of } \\
\text { RE specifically, the wider curriculum and/or schooling in } \\
\text { general. }\end{array}$ \\
\hline $\begin{array}{c}\text { Generic pedagogical and } \\
\text { psychological }\end{array}$ & $\begin{array}{c}\text { Generic pedagogical and psychological knowledge drawn } \\
\text { from educational studies, educational psychology and } \\
\text { cognate disciplines which is widely applicable across } \\
\text { educational settings and curriculum-subjects including RE. }\end{array}$ \\
\hline $\begin{array}{c}\text { Knowledge of the professional identities, roles and } \\
\text { and responsibilities } \\
\text { responsibilities of teachers, in RE specifically and in } \\
\text { general, including a knowledge and understanding of the } \\
\text { skills and competencies required. }\end{array}$ \\
\hline
\end{tabular}

\section{Research parameters}

In our exploration of the professionalisation of teachers of RI/RE in non-denominational, state-maintained, schools in England, from c.1934 to c.1978, the concepts and constituent elements summarised above have been applied in the following ways. First, in terms of professional self-organisation and professional politics, we focused on the origins, role and function of the Institute of Christian Education at Home and Abroad (founded in 1935, later becoming the Christian Education Movement, then Christian Education). With its successor, it became the pre-eminent organisation for RI/RE in the period and was foremost in offering professional development provision to RI/RE teachers. It drew together key clerics, academics, teachers and other stakeholders, and created a national network of members and local groups. The range and scope of its work makes it integral to any historical study of the professionalisation of RI/RE teachers. Detailed biographical information about many of the lead personalities in the early period of the organisation's history has been included in Table 3 in the appendix (those that are included in the table are marked with an asterisk $\left(^{*}\right)$ in the text). This shows the diverse ways in which the biographies of individuals intersected through ecclesiastical and educational networks and structures, and helps to contextualise the social dynamics of the discourses to which they contributed. For this strand of research, we analysed previously unutilised archival material on the Christian Education Movement held at the University of Birmingham, and consulted secondary biographical sources, such as the Oxford Dictionary of National Biography.

Second, in terms of professional knowledge, we drew upon a range of published primary documentary sources, focusing specifically on the contents of the journal of the Institute of 
Christian Education. This was initially called Religion in Education (est. 1934), but changed its name to Learning for Living in 1961, and then again, in 1978, to the British Journal of Religious Education. Discussions surrounding the journal's changing character and purpose reveal the complex and changing identity of the Institute of Christian Education as an organisation, as well as its relationship with the wider constituencies it sought to represent. The differences of opinion over the nature and purpose of RI/RE expressed in these internal disputes reflected wider debates about the identity, role and responsibilities of RI/RE teachers and the professional knowledge they should be expected to acquire and demonstrate. They were especially evident in the later stages of our focus period, when a Christian orientation of purpose for RI/RE seemed under threat.

With regard to both strands of research, we also surveyed an array of secondary sources, including unpublished theses by Dennis Bates (1976) and Cathy Michell (1985) which have been largely, and unjustifiably, neglected by the mainstream historiography of RE (Copley 2008). Contrary to these sources, which tend to emphasise the philosophical coherence of the discourse surrounding RI/RE, this article will demonstrate that there was never more than partial agreement about the subject's aims, and they were often contested, even if initially motivated by ecumenical co-operation.

For the purposes of this article, we have not applied the third concept of initial and continuing professional development, although subsequent research will look at the Institute of Christian Education's national network of membership groups, events and conferences, and its roles in supporting local authorities in the delivery of courses related to RI/RE. Thereby, and through the influence of its leadership, the Institute of Christian Education guided or organised a significant proportion of the professional development opportunities available to RI/RE teachers across the period.

A thoroughgoing history of the professionalisation of RI/RE teachers cannot be reconstructed properly without reference to wider social, cultural, religious and political events. Space does not permit a full exploration of such contextual influences here, but we have discussed them in other published studies (see Parker \& Freathy 2011a; 2011b; Freathy \& Parker 2012; 2013; Freathy et al 2015). We also do not attempt to provide here a history of wider Christian involvement in education, such as that represented amongst denominational societies across this period (Raftery 2012). Indeed, a systematic, denominationally-differentiated history of 
the religious curriculum of schools in the English context has yet to be written. Our concern is for RI/RE in non-denominational, state-maintained schools, and it is to the history of that provision in the period prior to our focus period that we now turn.

\section{Part Two: Non-denominational religious education}

\section{Legislation}

Before 1870, most schools in England were church schools; denominational religious observances were a daily occurrence, providing catechetical training and promoting active participation in a worshipping community (Hull 1975: 11). The Elementary Education Act of 1870 established locally managed non-denominational Board Schools (5-13 year olds) in England and Wales in order to supplement-rather than replace-the existing voluntary (church/denominational) school sector, thereby creating the dual system of denominational and non-denominational schools which, in an adapted form, continues until the present day. From 1870 to 1944, Board Schools (and, from 1902, Local Education Authority schools) were permitted to teach religion, but were not obliged to do so, thereby leaving the decision at the discretion of the local authority or occasionally the head teacher (Hull 1975: 145). Nondenominational religious education in Board Schools was constrained by three important legislative clauses during this period. First, a 'conscience clause' allowed parents to withdraw their children from any religious observance or instruction, and from school on days set apart for religious observance by their denomination. ${ }^{1}$ Second, to ease such withdrawal, a 'timetable clause' limited the provision of any religious instruction or observance to the beginning or end of a school session, thereby normally distributing responsibility for religious education across teaching staff and prohibiting the creation of a cadre of specialists. ${ }^{2}$ Third, the 'Cowper-Temple clause' stated that '[n]o religious catechism or religious formulary which is distinctive of any particular denomination shall be taught in the school'. ${ }^{3}$ In practice, in Board schools-as in church schools-there was little or no distinction made between RI and Worship. However, in Board schools, these religious observances were usually limited to reading and memorizing the Bible, the Ten Commandments, the Lord's Prayer and the Apostles' Creed in a spirit of 'careful formality' and 'strict neutrality' (Hull 1975: 12, 15). While most secularists and many Nonconformists opposed denominational religious education on the grounds that it might, for example, privilege Anglicanism, or usurp the rightful responsibility for religious education of worshipping communities, the majority of Anglicans and Roman Catholics opposed non- 
denominational Christian education, fearing that voluntary schools would become 'unchurched' (Cruikshank 1963: 62). For them, the behavioural (e.g. devotions, liturgies and recitations) and cerebral (e.g. creed and catechism) elements of Christian education were inextricably bound up with denominational identity (Hull 1975: 13). Thus, a denominational impasse effectively ensued. At this stage, it was clergy rather than teachers who were in a position to determine the professionality of those involved in religious education. Teachers' professional standing, however, was enhanced in the period after the 1870 Act, not least in relation to religious education, leading one Roman Catholic bishop to assert that teachers were beginning to 'fancy themselves wiser in their spheres than clergymen' (Murphy 1971: 63). Even so, the professional standing of teachers, specifically in relation to religious education, was at best no more than nascent in the early decades of maintained education.

The 1902 Education Act replaced School Boards with Local Education Authorities (LEAs), which were empowered to establish secondary schools for a limited number of fee-paying and, from 1907, non-fee-paying scholarship students (11-16/18 year olds). ${ }^{4}$ LEAs also took over responsibility for the running costs, but not building maintenance, of denominational schools through rate-aid (a local tax); in return they were permitted to appoint one-third of the school managers. ${ }^{5}$ In what may be viewed as a move to professionalise teaching in general, rather than religious education teaching specifically, the Act also transferred responsibility for providing religious education in denominational schools away from the local clergy - some of whom in single-school areas had significant influence- to the school managers, including lay members (Cruikshank 1963: 84). As state intervention in education increased, so denominational debate about what forms of Christianity (if any) the state should endorse became more vociferous. In 1902, Nonconformist opposition to the funding of Roman Catholic schools through rate aid ('Rome on the rates') led to one of the last great denominational controversies in parliament, as evidenced by the record breaking fifty-nine days of parliamentary debate, which discouraged a generation of politicians and policymakers from promoting reform of the school system (Chadwick 1997: 24).

Religious education was a profoundly political matter and the focus of protracted public controversy rooted in historic denominational disputes. These form the backdrop to, and are important in explaining, some of the urgency to develop secular and ecumenical philosophies of education which would respectively by-pass religious and denominational issues. Interdenominational goodwill, during the interwar period, added a favourable wind to such 
developments, creating conditions in which the professionalisation of RI teachers in nondenominational, state-maintained schools could occur.

\section{Interdenominational teacher training}

One example of early interdenominational co-operation in education, relating to the issue of professionalisation, was the development of the Selly Oak Colleges in Birmingham. This began in 1903 when George Cadbury (1839-1922), confectionery manufacturer and social reformer, transformed his home at Woodbrooke into a centre for Quaker studies. The formation of a group of other independent colleges swiftly followed: Kingsmead, an interdenominational mission college; Carey Hall, a missionary training hostel for women; Fircroft, a workers' college of adult education; and lastly, the Nonconformist Westhill College (Hastings 1991: 117-118). This latter college was established in 1907 in response to growing recognition that Sunday-school teachers and youth workers also needed to be trained and professionalised (Roberts \& Parker, in progress). Westhill was different because its religious and educational ethos was of North American influence (Priestley 2002; Priestley 2007; Roberts \& Parker, in progress). Its first Principal, George Hamilton Archibald, a Canadian educational psychologist and religious educator, advocated Froebellian-influenced, child-centred teaching, and Sunday-school lessons graded according to the growing child's needs. For complex reasons, his endeavours, and those of his associates, to reform Sunday schools and Sunday-school teaching were ultimately unsuccessful (Cliff 1986; Roberts \& Parker, in progress). Nevertheless, Archibald's ideas, and Westhill College itself, were influential in providing a professional knowledge-base for non-denominational religious education, and an interdenominational (albeit solely Nonconformist) institutional environment within which professional development could occur (Cliff 1986: 217). The second Principal of Westhill College, Basil Yeaxlee,* expanded the horizons of the college beyond Sunday-schools by introducing a one-year Diploma in Religious Education for prospective post-elementary schoolteachers, as well as ministers. Westhill continued to play a part in the development of RI/RE teachers and teaching until the early part of the twenty-first century. ${ }^{6}$ The earlier ecumenical concern to train Sunday-school teachers and Christian missionaries led to developments which sought to raise the standard of religious teaching in mainstream English schools as part of a growing belief that Europe and North America were valid mission fields alongside those of Africa or Asia (Freathy, 2005: 103; Doney 2015; Roberts \& Parker, in progress). It was recognition that teachers of RI/RE could benefit from specialized advanced training and the acquisition of differentiated knowledge. 


\section{Interdenominational curriculum formation}

Another influential example of Christian co-operation, occurring after the First World War, was the development of 'agreed syllabuses' for RI, which were later made statutory in the 1944 Education Act. Agreed syllabuses represented a means of achieving and/or expressing interdenominational co-operation (Louis 1985), and marked a major advance by promoting an ecumenically-acceptable form of Christian teaching in schools (Bates 1976). The processes leading to their development also provided a political structure by which LEAs could garner the support of the churches for the expansion of LEA secondary school provision (Cruikshank 1963: 121). ${ }^{7}$ Prior to the instigation of agreed syllabuses, some within the churches were both concerned about the implications of secondary school expansion for their role in the education system, and apprehensive about the nature and place of RI within the newly-formed secondary schools. This was seen to be a particular issue for those students progressing from voluntary (church) elementary schools to county (LEA) secondary schools. The Anglican Church, for example, could not afford to build its own secondary schools. It was already struggling to fulfil its financial responsibility for elementary school buildings and repairs and, by the interwar period, many Anglican schools were closing or being handed over to LEAs (Grimley 2004a: 14). Yet the Church of England wished to retain a stake in the national education system and was increasingly concerned about RI in schools, including LEA schools, not least because investigations during the First World War had revealed the parlous state of the religious knowledge of the men at the front (Committee of Enquiry upon the Army and Religion 1919). According to Matthew Grimley, ‘[a] great deal of Anglican energy and rhetoric after 1918 was directed at reclaiming these people, and turning their diffusive Christianity into religious observance. Churchmen realized, for example, that they would have to grasp the nettle of religious education' (Grimley 2004a: 14).

Early agreed syllabuses included the County Council of the West Riding of Yorkshire: Education Department Syllabus of Religious Instruction (1922) and The Cambridgeshire Syllabus of Religious Teaching for Schools (1924). ${ }^{8}$ Agreed syllabuses had to be theologically and educationally acceptable to those Christians in each locale that were responsible for defining them. They aimed to provide detailed and systematic schemes of work on biblical material and biographical illustrations of heroic Christian lives, in order to teach school pupils religion and morals (Leeson 1948: 241). The syllabuses also contained LEA policies regarding education and religious education, and theological essays on relevant 
topics, such as ‘science and religion’ or ‘modern biblical scholarship’. Eminent scholars from across a range of denominations filled agreed syllabus committees, as can be seen by the list of educators who were consulted by the West Riding Education Committee in preparing their syllabus of $1922 .{ }^{9}$ This diverse membership provides an example of the constraints upon $\mathrm{RI} / \mathrm{RE}$ teacher self-regulation and the limits of their autonomy to determine professional knowledge, standards and expertise in the area they profess. Not only was their independence curtailed by the internal structures and processes of the public service in which they were employed, but also by the involvement of external stakeholders, most notably the churches, in defining, governing and supporting religious education (Freathy et al 2016).

According to John Hull (1975: 13, 15, 19), agreed syllabuses were dedicated to the more 'doctrinaire' approach of the 'new religious education' which emerged from the 1920s, and which promoted personal and corporate spiritual growth and the new theological and educational idea that 'all education rightly conceived is religious education'. Hence, every subject and the whole life of school was deemed to have implications for Christian nurture and character development. For Cathy Michell (1985: 48), the compilation and use of agreed syllabuses, as well as the innovative opinion of which they were an expression, can be understood as indicating the existence of a distinctive 'Era of Agreed Syllabuses' (19201965) in which non-denominational RI was provided with an increasingly coherent ecumenical nature and purpose. In turn this would facilitate the creation of an increasingly coherent body of professional knowledge and professional development opportunities alongside.

\section{Interdenominationalism and ecumenism}

The participation of Anglican and Nonconformist representatives in the interdenominational processes by which agreed syllabuses were determined was facilitated by a range of factors (Freathy 2005: 42-43 and 57-58). The slow erosion of the connection between Anglicanism and English identity, and the removal of many of the civil disabilities affecting Nonconformists, meant that the sense of injustice which had fuelled their pre-First World War educational campaigns had quelled somewhat. A whole host of reforms reflected a formal recognition that England was denominationally pluralistic, and that the state has a responsibility to maintain public law and order, but little right to interfere in private religious matters (Heater 1990; Freathy 2005). These reforms included the repeal of the Test and Corporation Acts (1828); the emancipation of Roman Catholics (1829); the abolition of 
Church rates (1868); the repeal of doctrinal tests for university entry (1871); the granting of permission to Nonconformists to use Anglican graveyards (1880); the full emancipation of Jews (1890); and the establishment of secular parish councils (1894). Later, in further developments, there was a growing willingness among some groups within the Nonconformist tradition to reunite with the Church of England, as demonstrated by the approaches made by the influential Wesleyan Methodist John Scott Lidgett* and the Secretary of the Baptist Union John Howard Shakespeare. This meant that the Church of England 'could more plausibly make an appeal in the name of Christianity as a whole' with increasing support from Nonconformists (Grimley 2004a: 14). Other signals of ecumenical co-operation across the 1920s, exemplified by the important interdenominational Conference on Christian Politics, Economics and Citizenship in Birmingham in 1924, indicated a greater willingness amongst English Christians to collaborate on matters of common concern (Oliver 1968: 66; Flindall 1972: 388; Machin 1998: 32-33).

Anglican and Nonconformist co-operation in the promotion of non-denominational Christian education was also influenced by the rise of modern liberal theology (Hull 1975: 15) and the growing international ecumenical movement. The emergence of an ecumenical intellectual group lobbying for Christian education was one initiative amongst many directly resulting from the World Missionary Conference in Edinburgh in 1910. This conference has been heralded as 'the real start of the modern ecumenical transformation of Christendom' (Hastings 1997: 87; cf Doney 2015) and was itself a legacy of a period of Victorian evangelical missionary zeal; this was particularly evident amongst British university graduates, leading to the foundation of the Student Christian Movement (SCM) in 1898 (Freathy 2005: 56). Many of the personalities associated with SCM and the Edinburgh conference, who grew into a socially-conscious, politically-active and interdenominational elite in the interwar years (e.g. Tissington Tatlow*, J. H. Oldham* and William Temple*), also came to be influential in the burgeoning Christian education movement, and in the development of an ecumenically-minded view of religious education in schools, with its own organisational structures, and the means to disseminate professional knowledge and a sense of professional identity and responsibility.

Against this background, and for the first time in such detail, the article next explores the professionalisation of RI/RE in non-denominational, state-maintained schools, with reference to original archival evidence. It does so by elucidating how teachers of the subject began to 
be organised through the activities of 'Christian educationists', including clerics, academics, teachers and other stakeholders, and the ecumenical and theologically-liberal movements of which many of them were members. In common with many curriculum subjects across this period (Ball 1985), religious education (broadly defined) developed its own networks and social circles, its own organs for transmitting knowledge and forms of disciplinary socialization, its areas of common ground and common frames of reference, as well as an emergent tradition and leading elite (Becher \& Trowler 2001). Nevertheless, as will be shown later in the article, interdenominational co-operation surrounding the professionalisation of teachers of non-denominational RI/RE was to be continually tested in practice by the diversity of Christian perspectives and the changing social, religious and academic climate.

\section{Part Three: Organising religious education professionals}

\section{Christian education at home and overseas}

At the 1910 World Missionary Conference in Edinburgh, missionaries gathered from around the world, although Anglo-American groups predominated (Doney 2015). They complained that, although converted peoples could repeat Christian words and actions, the basic structure of their national lives remained unchanged (Hull 1975: 146). Hence, there was a need to refocus ecumenical missionary activity on the 'Christianisation of national life'. With this in mind, the education committee, under the Anglican Bishop Charles Gore, called for the application of modern educational theory and practice (akin to what we have called generic pedagogical and psychological knowledge), so as to educate the whole personality rather than simply promote rote learning (World Missionary Conference 1910; Edwards 1971: 299-300; Freathy et al 2014; Doney 2015). By then, however, in England, the number of SCM members volunteering for foreign missions was in decline, their evangelistic zeal instead being channelled through allied organisations. These included the Auxiliary Movement (AM), established in 1912, which enabled members of the SCM staff to keep vocations alive amongst young Christians by promoting Christian education at home as much as missionary activity abroad. In 1922, the AM founded a Schools Department to oversee the organisation of camps and conferences for children. Its stated objective was to equip unqualified teachers, especially in relation to the teaching of RI, and to consider the aims and methods of schooling from a Christian standpoint (Bates 1976: 316). Because of anxiety over causing denominational division, the AM emphasised theological ideas about which there was perceived to be most agreement, namely the implications of Christ's life and work, the 
coming Kingdom of God, the Christian way of life and Christian comradeship (Bates 1976). It developed various principles for non-denominational RI, such that the Christian faith should be presented in the light of modern knowledge, in an atmosphere free from emotionalism, and without an attempt to force ‘decisions' on young people (Sutcliffe 1984). In this sense, the AM prepared ground for later developments in RI/RE. Moreover, its leaders, notably Tissington Tatlow* (then Chairman of the General Committee) and Basil Yeaxlee* (then a member of its General Committee), were to be key figures in the history of the Institute of Christian Education at Home and Abroad.

In April 1931, the AM and the Advisory Council for Christian Education Overseas ${ }^{10}$ jointly ran a teachers' conference at Swanwick in Derbyshire on 'Christian Education at Home and Overseas'. This conference gave rise to a number of initiatives of long-lasting import in relation to RI, affirming the longstanding inter-relationship between English missionary endeavour and its Imperial interests abroad. For those in attendance, the Christian gospel was understood to be a Protestant-English one, even if it was sometimes asserted that children and teachers at home may learn from those overseas. ${ }^{11}$ Similarly, at this stage, religious education was assumed to be equated with Christian education, and each was regarded as an arm of missionary education (Doney 2015). Religious education was also understood in a holistic sense; the purview of the doctor and priest as much as the teacher. J. H. Oldham* was one of the key speakers at the Swanwick conference, to which he submitted a preliminary paper entitled Christian Education: Its Meaning and Its Mission (1931). In this he asserted that, in order for the Christian Church to be a saving, regenerating, vitalising, creative force in the world, it was necessary to establish a body of Christian teachers who would help one another in a real fight against faithlessness and fear, in order to change the ideas of their time and humankind's conceptions about the meaning of life. Others, amongst the 250 delegates in attendance, were in agreement with Oldham's suggestion that an organisation 'should be created in England to undertake a continuous systematic and coordinated study of the various aspects of Christian education'. ${ }^{12}$

\section{Towards an institute of Christian education}

Following the April 1931 Swanwick conference, a Continuation Committee was formed to advance the work of the Conference and initiate schemes in connection with the recruitment of staff for overseas work, short service, and the linking up of home and overseas 
institutions. ${ }^{13}$ More important were two developments emerging from the final resolution of the Conference was that:

This Conference would welcome the formation of an association of those concerned with religious instruction at home and overseas, with a view to the raising of its standard and efficiency, and that it accepts the offer of Miss Stone, Bristol University, to make preliminary inquiries on this subject. ${ }^{14}$

The long-term goal was the establishment of an Institute of Christian Education, which could ensure that 'the two great forces for good, Christianity and education' are co-operating rather than working separately. However, this plan 'had not been put before the Conference as a whole because it was felt that the members might not wish to commit themselves to immediate opinion on such a far-reaching proposal'. ${ }^{15}$ With this ambition in mind, the Continuation Committee authorized some of its members to approach William Temple* (then Archbishop of York), to discuss the scheme. Temple was sympathetic and invited a select group of individuals to form "The Christian Education Group (Provisional) for the Consideration of Problems affecting Christian Education in our time at Home and Overseas', for which three main lines of work were distinguished: 'the gaining of a clear idea of the significance and content of Christian education; the examination of its present aims and methods; [and] the encouragement of experimental work through conferences, literature, and personal relationships' ${ }^{16}$ Amongst those invited to attend were many theologians, academics and teachers whom were later to become formative to the history of Christian education in England as a whole. ${ }^{17}$ Those attending the first meeting in July 1932, for example, were the aforementioned Tissington Tatlow*, J. H. Oldham*, and Basil Yeaxlee*, but also Arthur Mayhew*, Walter Moberly*, and Oliver Quick*. Early records from this group show a division in labour between those 'who will consider the general lines on which investigation should proceed' and those 'possessed of leisure and ability' who will 'do the actual work of investigation' as well as 'serving as executive officers'. ${ }^{18}$ The three appointed executive officers were Tissington Tatlow*, E. Addison Phillips* and W. W. Vaughan*.

The second development to emerge following the Swanwick conference was the establishment of an Association for Teachers of Religious Knowledge (ATRK) by the 'Miss Stone' mentioned in the conference's final resolution. Although the meeting of the Continuation Committee in May 1931 permitted Stone to form a provisional committee to develop the Association, it curtailed its full establishment, asking her to 'postpone the more definite organisation of the Association' until they had opportunity to further consider the 
matter in the light of the plans to form the Institute. ${ }^{19}$ In addition, they stipulated that 'membership of the Association [ATRK] should be on a professional and technical basis' comparing it to other professional teacher associations, and widening it to include teachers from overseas. ${ }^{20}$ During the Summer and Autumn of 1931, work to establish ATRK carried on. At the Continuation Committee meeting on $2^{\text {nd }}$ October 1931, it was reported that 'Miss Stone had had many letters of enquiry about the Association, and that about 100 had sent the 5/- subscription to the Association by the end of July'. ${ }^{21}$ Later in the same month, it was reported that 'Miss Winifred Mercier' had been appointed provisional 'Chairman', and it was hoped that Sir Henry Hadow* would become President. Furthermore, it was noted that, despite the unfortunate death of Stone-which was described as a great blow to the Association-an inaugural meeting was planned for the following January. ${ }^{22}$

ATRK, under the presidency of Hadow*, thus became the first association for teachers of 'RI' in Britain. In the history of the professionalisation of RI/RE teachers, it is significant as an organisation for teachers, developing collegial occupational relationships and mutual support, even if it does not represent self-organisation by them. The Association held its first General Meeting, attended by 78 people, on $5^{\text {th }}$ January 1932. Its stated objectives were to represent the needs of the subject to LEAs and other interested bodies, and to enlist the help of scholars in forming a link between research in the universities and teaching in schools, ${ }^{23}$ thereby it would facilitate the development and dissemination of advanced and differentiated professional knowledge. ATRK's first conference was held two years later at Whitelands College $\left(4^{\text {th }}-8^{\text {th }}\right.$ January 1934), which included lectures, discussions and the passing of a resolution which was supportive of specialised and advanced training:

That this meeting, convened by the [ATRK], is of the opinion that the improvement of religious teaching in the schools of this country is dependent to a large extent on the growth of a body of men and women specially qualified in the subject, so that in the majority of schools there could be a member of staff capable of advising on the planning of the syllabus, the choice of books for reference or study, etc., and who could take a considerable but not exclusive part in the teaching of the subject (Matthews 1934: 103).

\section{Institute of Christian Education at Home and Abroad}

In April 1934, approximately 179 university and college teacher trainers, headteachers, teachers, missionaries, and clerical and lay representatives of the churches attended the Second Christian Education at Home and Overseas conference at Swanwick, Derbyshire (Gwyer 1934). The constituencies represented by these delegates evidence the complexity of 
multi-stakeholder politics surrounding religious education which itself had a multidimensional character. At the conference, lectures and discussions were held and a resolution was passed to found an Institute of Christian Education at Home and Abroad (ICE). As a result, in 1935, the Continuation Committee of the Conference on Christian Education at Home and Overseas, the Christian Education Group (Provisional) and the ATRK came together to form the ICE. The process of unification was not straightforward, and there was much careful negotiation, particularly regarding the constitutional status of the ATRK. ${ }^{24}$ William Temple* became the ICE's first President; Tissington Tatlow* became its first director, and Sir Henry Hadow* and John Scott-Lidgett* became Vice-Presidents. The ecumenically-influenced ICE considered the nature of religious education, promoted Bible study which was spiritually and critically informed, and attempted to increase the resources and improve the methods of RI teaching in schools (Yeaxlee 1936a). It also acknowledged that some children and young people were 'finding faith difficult', and it sought to aid and unify teachers and pupils who came from different denominational backgrounds (Reeves 1999: 102). Here we can see how the ICE, especially through the work of ATRK, fulfilled a role in organising religious education professionals, and in developing and promoting, what we have called, orientative knowledge, subject-specific content knowledge, and knowledge of subject-specific pedagogical methods.

William Temple* gave the address at the dedication of the inaugural meeting of the Council of the ICE on $30^{\text {th }}$ June 1936. With wider international events looming large, he discussed the European political forces, which interpreted life's meaning only in terms of human history and nation-states, causing anxiety for those who cared about religion, and he criticised humanistic attempts to preserve religious values without the necessary transcendent element (Temple 1936). In addition, he reasserted the authority of religious experience and the necessity of good quality religious teaching of future generations. For Temple, the latter should produce a far larger body of reflective and intelligent believers than there were at that time, in order to preserve the British religious tradition and to give it the influence which it was due among the countries of the world (Temple 1936: 182). Thus, he held that the ICE should be concerned with clarifying the aims of religious education and 'take care that what is being presented is the most enlightened interpretation of our tradition in accordance with modern scholarship and living contemporary thought' (Temple 1936: 181). Temple's articulation of a vision for religious education at the founding of the ICE was indicative of his own substantial contribution to the development of religious education and the dual system 
until his death in 1944 (Green 2011: 211-241). For him, and many others, the professionalisation of religious education would counter the secularisation and deChristianisation of society by ensuring that the whole of school life provides training in Christian citizenship (Parker 2005: 202; Freathy 2008b: 109).

By 1939, the ICE had nearly 2,000 members and over 3,000 by 1945 . Its main concern was to improve the standard of religious education by producing books, pamphlets and tracts, as well as providing a forum for debate. In these ways, the organisation contributed to the development of RI as an emergent subject, offering the resources to build a professional knowledge-base, and the means to disseminate it. Publishing a journal became an important way of (1) asserting the role and function of the ICE, as the only interdenominational organisation supporting religious education in the period; (2) disseminating pertinent professional knowledge to teachers; and (3) advertising initial and continuing professional development opportunities.

\section{Part Four: Forming and disseminating professional knowledge}

\section{Religion in Education}

Hugh Martin of the SCM Press had called for a journal of Christian education as early as 1932 and this suggestion came to fruition in the form of Religion in Education, which was launched in 1934. ${ }^{25}$ Its Editorial Board included: Canon G. D. Baker (Diocese of London and Southwark); Deaconess Dorothy Batho (Principal of Whitelands Training College); J. L. Christie (Headmaster of Westminster School); and Canon Spencer Leeson. Religion in Education became an important forum for promoting dialogue about religion in education, and it reflected and promoted the growing professionalism among religious educators through campaigns for better staffing, curriculum resources and teacher training.

According to Copley (1998), between 1934 and 1939, topics covered by the journal were: the Bible and theological issues at teacher level (49 articles); teaching notes for specific topics at classroom level (42 articles); articles on the interface between religion and education (21); school worship (10); teaching world religions (4); and additional articles on religious education in other countries (e.g. China). Dominant in the minds of many contributors to the early issues were the matters of secular influences at home and 'paganism' abroad, in opposition to which religious education in schools was seen to be a potent force (Freathy 
2007; Parker 2012). They were keen to define and orient religious education in specific and clear ways (Freathy et al 2014). For instance, an article in the first issue by the High Church Anglican, Lord Irwin (later to become President of the government's Board of Education), signalled the extent of growing establishment and government approval for religious education, but also the degree to which this endorsement was caused by the many powerful, disintegrating and hostile ideological forces that were at work (Irwin 1934). For Irwin, the perpetuation of English moral values and character necessitated the continuing influence of Christianity, which undergirded them. He held that RI inculcates faith, conviction and an attitude to life, so long as it is taught by teachers who are not only technically competent, but profoundly convinced of the reality of their faith and eager to bring others to the same conviction (Bates 1976: 220-221). For all contributors to Religion in Education, English traditions and values could only be defended against radical, secular and/or political ideologies by the bastion of Christianity (Freathy 2008). W. F. Mitchell (1937) and B. W. T. Handford (1937) respectively contrasted Christianity with the new anti-semitic, uncritical and mystic German religion, and compared it with the greed and materialism of business and the pride and nationalism of patriotism (Copley 1998: 84). In a similar vein, the journal's first editor, Basil Yeaxlee, ${ }^{*}$ wrote:

The totalitarian states have left neither their citizens nor the world in doubt as to their practical philosophy of life and have ruthlessly refashioned their educational systems into instruments for the production of faith and obedience in their young people. The children of this world have been wiser than the children of light in perceiving the connection between education as a whole (not schooling only) and life as a whole. But they have deified the state and disregarded persons. ... Christian education demands that worship, religious instruction, the general curriculum and organisation, school life and that of home, church and city, vocational and continued or higher education and not least, recreation, shall be of one piece and shall be in conformity with the mind of Christ. (Yeaxlee 1940: 61-62)

Although believing that the English tradition of Christian values alone could thwart secularism and 'paganism', Yeaxlee maintained that the efficacious transmission of Christianity would require the Christianisation of both education and society (Yeaxlee 1941a, 47; Chorley 1984; Freathy 2005: 108ff). To this end, he hoped the success of the ecumenical movement (Behenna 2001: 79; Doney 2015) and of the Christian unity present in the formation of agreed syllabuses, would spread throughout the entire Christian community (Yeaxlee 1937c: 182) as it embarked upon a missionary task (Copley 1998: 84-85).

\section{Basil Yeaxlee}


Throughout his career, Yeaxlee* campaigned to ensure that education was religious and that religious education was professional. During his 23 years as editor of Religion in Education, he encouraged educationists to look at the 'why', 'how' and 'what' of RI (Yeaxlee 1934b: 61), and sought to resource all the elements of professional knowledge:

We set out with the ambition of providing something relevant to the special interests of everyone in every issue. We envisaged a kind of general pattern comprising Biblical Studies, aims and methods in teaching, worship, the relationship of Scripture to other elements in the curriculum, the psychology of religion and of religious growth in childhood and adolescence, questions of educational policy, enterprise and experiment in religious education overseas, news, and information about books (Yeaxlee 1937a: 1).

An analysis of some of Yeaxlee's early editorials illustrates some of his main concerns and the emphases of the journal as a whole at this stage (Freathy 2005: 108-110). It also demonstrates coverage, however unevenly, of all constituent elements of professional knowledge in RI/RE, thereby providing some validation for that conceptual framework.

First, Yeaxlee expressed deep commitment to increasing the professionalisation of RI, especially the advancement of subject-specific content knowledge, to ensure that pupils grew up with knowledge of Christianity and scripture. He deplored ignorance of the Bible and the basic facts of the Christian religion, which he believed was becoming commonly displayed by otherwise well-educated young people (Yeaxlee 1935b: 122). He advocated many reforms concerning initial and continuing professional development: the employment of women with theological training; the improvement of training provision for RI specialists; the provision of optional Divinity courses for initial and in-service teacher training; and the ability of all teachers to decide whether they wished to teach RI (see, for example, Yeaxlee 1936b: 62). Yeaxlee recommended various ways in which teachers could equip themselves to give improved RI teaching (e.g. university extension courses, public theological lectures, the SCM, the Church Tutorial Classes Association, Board of Education courses, and reading numerous booklists and pamphlets). For instance, he noted that many LEAs, since adopting agreed syllabuses, had provided special courses of lectures on the biblical passages contained in their syllabuses (Yeaxlee 1934c: 193). He also commended the ATRK for bringing teachers and biblical scholars together in the promotion of Scripture teaching, on a high level of professional competence as well as in a spirit of true understanding (Yeaxlee 1934c: 193194). 
Second, promoting knowledge of subject-specific pedagogical methods, Yeaxlee was committed to reforming the curriculum content and pedagogy of RI. He was keen that the recent upsurge in the number of novels, plays and films which portrayed biblical material should be used imaginatively by teachers to make biblical stories come alive (Yeaxlee 1935c). He wanted scripture to be taught as a text written in a real historical situation whose message pertains to then and now, not as a literary or ethical museum piece (Yeaxlee 1937b). He also recommended that pupils should be encouraged to read specified religious books supplied by school libraries for recreation (Yeaxlee 1935b: 122) because of the paucity of curriculum time allocated to religion (Yeaxlee 1935b: 121). Moreover, he maintained that, because the real issue was not what should be taught, but when and how, syllabuses should prescribe subject content applicable to each stage of child development, thereby reflecting his own broader generic pedagogical and psychological knowledge. In addition, Yeaxlee criticised the secondary and public schools for the chaotic RI — which they provided —and for the entire lack of co-operation which existed between their RI teachers (Yeaxlee 1936c: 122).

Third, moving beyond RI to consider the school system in which it occurs, Yeaxlee was concerned with who controlled education. He hoped that the inefficient, inequitable, undemocratic, and therefore un-Christian, dual system of church and state schools would be replaced by non-denominational RI and Collective Worship. He believed that the churches should work to provide every person with the fullest education commensurate with their capacities, and that this should be achieved in co-operation with the state, so long as the 'State is Christian, or friendly though neutral' (Yeaxlee 1937c: 181). This was because, even where humanist educational aims were in accordance with the will of God, Yeaxlee believed that no education is adequate without the living encounter with God and the response of personal faith (Yeaxlee 1937c: 62).

Fourth, in terms of orientative knowledge and his overarching philosophy of education, Yeaxlee was critical of education which was bookish, competitive, utilitarian and depersonalising, and which was characterised by a feverish scramble for secondary-school places, School Certificates and university scholarships (Yeaxlee 1941b: 135). He believed that the spirit and values of Christianity should permeate the whole curriculum and life of a school because otherwise the specific study of the Bible in RI would be but an academic exercise and formal worship only a respectable custom (Yeaxlee 1934a: 1). 
Lastly, Yeaxlee held that the aim of religious education should not be to develop a knowledge of history and ethics, or to gain acceptance of creeds and the observance of ceremonies for their own sake. Instead, it was to ensure that those who teach and those who learn should see and follow what, in the New Testament book of Acts of the Apostles, is called 'The Way' (Yeaxlee 1935a: 2). For teachers to gain knowledge of this role and responsibility, it was necessary to reverse the secularisation of adult education, colleges and universities so that prospective teachers can be enthused by a sense of Christian vocation.

As a vehicle for disseminating professional knowledge, Religion in Education played a role in the professionalisation process, both promoting and reflecting growing professionalism amongst all those concerned for religious education. Yeaxlee's editorials provide insights into his wide-ranging understanding of the professional knowledge required to be an RI teacher in the 1930s and 1940s, and locate RI and its teachers firmly within a wider educational and professional context. His was a more wide-ranging conception of professional knowledge than that evident in the articles of many other writers of the time, who often tended to ignore knowledge of subject-specific pedagogical methods and generic pedagogical and psychological knowledge. To some extent, this omission can be seen as symptomatic in England of a general neglect of pedagogy (i.e. the act and discourse of teaching) in public, political and professional discourse, and an over-reliance on pragmatism combined with ideological ends (Simon 1981). However, in an international context characterised by profound social, cultural and political change, it is perhaps understandable that so much attention was given to constructing and articulating orientative knowledge based on shared ontological and epistemological foundations. Only this could provide aims and purposes for religious education, the wider curriculum and schooling in general, and inform knowledge of the professional identities, roles and responsibilities of teachers.

\section{Orientative knowledge}

By the 1940s, there was an identifiable interdenominational movement for Christian education with its own leading intellectuals drawn from a multi-stakeholder constituency of university and training college lecturers, secondary school teachers, educational administrators, lay and clerical church members, writers and politicians. As illustrated by the appended Table 3, those leading developments to professionalise religious education shared similar social and educational backgrounds (often public schooling followed by Oxbridge matriculation). According to John Hull (1975: 23), their attitudes and beliefs had become so 
self-conscious and coherent that they constituted a 'philosophy of religious education', one which held sway in schools until the mid-1960s. The ICE played a key role, for example, establishing a Standing Committee on Study and Research in 1937 to work towards a Christian philosophy of education, and sponsoring an associated Readership at Manchester College, Oxford (Freathy 2005: 106). As the pre-eminent organisation for those concerned with non-denominational religious education, the ICE's network of committees, conferences and publications provided the chief medium for disseminating a body of orientative knowledge, both locally and nationally, and providing teachers with a structure in which to develop and maintain a collective sense of professional identity, role and responsibility.

On the development of Christian education between c.1920 and c.1965, Dennis Bates (1976) and Cathy Michell (1985) both argue that the dominant viewpoint, alongside a decidedly liberal, ecumenical and Protestant line, was that of British Idealism, which promoted a broad and universal understanding of religion, sitting loose to particular denominational ties. Idealism led Christian educationists, such as Oldham and Yeaxlee, to use the three concepts of 'education', 'religion' and 'life' vaguely and often interchangeably (see Doney 2015). Bates (1976: 50-51) argues that they equated education with life because education was held to be lifelong, present in every human context, and concerned for the whole development of every aspect of personal and communal existence (e.g. physical, mental, moral and spiritual spheres); it was not confined to one period of life, formal educational settings or the training of one human faculty. Education was also equated with religion because Christian educationists held an Idealist belief that the meaning and purpose of education, as of life itself, should conform to the ordered wholeness and purpose of ultimate reality, which they defined in terms of the Christian God (Bates 1976: 81-82). Thus, the meaning and purpose of education is to bring humankind face-to-face with questions of the deepest meaning with the aim of fulfilling the highest purpose of redeeming the world and history itself (Bates 1976: 53). The task of religious education was to awaken in children and adolescents - at a stage when religious instincts and spiritual questioning were believed to be most unselfconsciously exhibited-a consciousness of reality, permanence and the eternal, and a realisation that everyday feelings and experiences are revelatory of reality, truth and God (Michell 1985: 56, 60 and 62). The potential for chaos, fragmentation, disunity and aimlessness to occur in childhood and adolescence would be prevented by an affective Christian education, promoting the natural growth, nurture and cultivation of the whole person, and made relevant 
to lived experience, by breaking down the divisions between different forms of curriculum and between school and life (Michell 1985: 63 and 75).

The exemplar was the Arnoldian public school (Copley 2002) in which religion was thought to rise above being a subject of teaching and instead become a way of living (Bates 1976: 36). Rather than being merely taught in the abstract as a school curriculum subject (RI), religion was to be caught through religious education in a broader sense. This would incorporate the devotional (e.g. Chapel services, Holy Communion, Confirmation), academic (Scripture teaching and doctrinal teaching involved in preparation for devotion), practical (Voluntary services and societies), and pastoral (the personal examples of masters) (Bates 1976: 185-6; Freathy 2005: 129). The establishment figures who took centre-stage in the history of religious education at this time often sought to apply the lessons they had learned personally from the English public school system to non-denominational, state-maintained schooling, not least in conceptualising RI firmly within the context of the corporate life of schools (Bates 1976: 113, 119; Freathy 2005: 131-3; 2008b: 104). Such a conceptualisation had ramifications for the professionalisation of teachers of $\mathrm{RI} / \mathrm{RE}$ because it had the potential to undermine the idea that such teachers are set apart from other occupational groups (namely other teachers and school chaplains) by particular personal qualities and characteristics, such as the acquisition of specialised, advanced and highly differentiated knowledge, or exclusive practical expertise.

According to Bates (1976: 59-60), Christian educationists agreed—on the whole-that all philosophies of education must be subordinated to their 'religio-idealistic' objectives. When secular and religious aims are compatible (e.g. to produce a good citizen or to develop character), it was argued that such aims could only be achieved fully within the framework of Christian education. Furthermore, having deemed education to be naturally and unavoidably indoctrinatory because it automatically and unconsciously instils society's predominant value-system, Christian educationists were convinced that education in a non-Christian society could not be regarded as full or true, and that indoctrination should become selfaware and premeditated. Some even advocating the propaganda methods used by National Socialists in Germany (Michell 1985: 87-90). Where homes and churches had both failed to fulfil their Christian missions, schools were called upon, in an act of revolutionary social reconstruction, to take over responsibility for transmitting the Christian essence of English national identity (Michell 1985: 85, 154, 179, 208-209). This was justified with reference to 
an idealised account of England's Christian past, when the political, social and intellectual realms functioned harmoniously under one overarching Christian philosophy (Michell 1985: $171 ; 213-216)$, and with regard to the vestiges of this heritage that were still deemed to be apparent in national life (Michell 1985: 85, 77, 184; Grimley 2007). However, because society was seen as overwhelmingly secular, pluralistic and immoral (Michell 1985: 84-85 and 129), Christian educationists held that—as far as possible—only unidirectional contact between school and society was permissible, with schools influencing society's beliefs and values, but not vice versa (Michell 1985: 255-256). Affording schools the eschatologicallysignificant role of training citizens for the Kingdom of God (Michell 1985: 263), Christian educationists maintained an optimistic view of the capacity of schools to counter the evils of contemporary secular society by restoring the Christian social order (Michell 1985: 91, 115, 241, 256), choosing between Christ and the Anti-Christ, Christendom and Heathendom, and Truth and Falsity (Michell 1985: 125), so as to avoid the cultural and moral chaos evident within totalitarian European states (Michell 1985: 132).

The professionalisation of RI teachers was part of a more comprehensive process seeking to professionalise all teachers concerned with religious education. The multi-stakeholder constituency of Christian educationists contributing to the above discourses promoted what appears to be a coherent Christian philosophy for education in general. They did so more vociferously than they articulated aims, methods and content for RI specifically. The body of orientative knowledge and knowledge of professional identities, roles and responsibilities that they endorsed potentially implicated all teachers. Those with a specific responsibility for the curriculum subject of RI had to relate their professional practice to education, religion and life broadly, and orientate it towards a transformative social agenda, based upon assumptions about the nature of reality, truth, human development and national identity. However, the heightened concern of Christian educationists for ideological ends rather pedagogical means meant that the professionality and individual professionalisation of teachers of RI was underconceptualised. The types of knowledge promoted for the broader constituency under their purview drew upon the ontological and epistemological foundations of religious education, its overarching aims and purposes, and the consequent professional identity, role and responsibilities of Christian teachers.

\section{Education Act}


To a large extent, the Second World War provided a cultural climate which was more open to the prospect of radical religious and educational reform along the lines mooted by Christian educationists than perhaps at any other time in the twentieth century (Freathy 2007; Parker 2012). Exploiting this opportunity, they pursued an ecumenical agenda for the pragmatic purpose of securing the presence of Christianity in the nation's schools. The greater coherence with which they conceived the nature and purpose of religious education was garnering an increasingly positive response from the government's Board of Education and its Consultative Committee. Instead of the traditional view of religion as denominationally divisive, non-denominational religious education could now be viewed as nationally cohesive and professionally credible. To a degree, the aspirations of Christian educationists were reflected in the statutes regarding religious education in the 1944 Education Act.

The 1944 Education Act, which is primarily known for introducing free secondary education for all 11-15 year olds, stipulated that all pupils in England and Wales, except those withdrawn by their parents in accordance with the existing 'conscience clause', should be provided with RI and daily Collective Worship. ${ }^{26}$ This was a stipulation barely imaginable pre-war. The Act also made more widespread, by statute, the increasingly common practice among LEAs of devising or adopting an Agreed Syllabus of RI. By law, these syllabuses now had to be agreed unanimously by four committees representing the religious denominations of the locale, the Church of England, the teacher associations and the LEA. ${ }^{27}$ They had to adhere to the 'Cowper-Temple clause' by not being distinctive of any particular denomination. ${ }^{28}$ In addition, the 'timetable clause' was dropped, so that in theory the subject could be taught by specialists at any time of the day rather than being limited to the beginning or end of school sessions, which were times dominated by administrative and pastoral matters. LEAs were also permitted to establish Standing Advisory Councils on Religious Education to advise them on matters pertaining to Agreed Syllabus instruction. ${ }^{29}$

The Agreed Syllabus Conferences and Standing Advisory Councils on Religious Education contributed to the professionalisation of RI/RE teachers by providing: (1) an organisational process by which teachers, along with others, might determine the nature and purpose of the only statutory curriculum subject; (2) an institutional structure for the development and dissemination of advice and guidance affecting professional knowledge, standards and expertise; and (3) a local forum in which collegial occupational relations and mutual support might contribute to the development of all professionals involved. At the same time, 
however, they had the effect of placing RI/RE teachers in a minority position in terms of the statutory structures designed to define, govern and support religious education, and thereby limited teachers' freedom to determine their own professional knowledge, standards and expertise.

Overall, the religious provisions of the 1944 Education Act meant that a greater supply of RI teachers was required, particularly for the burgeoning secondary school sector. Much of the responsibility for this lay with the church teacher-training colleges and with religious organisations, such as the ICE, rather than the Board (and, from 1944, the Ministry) of Education. The 1944 legislation, which some later regarded as a missed opportunity because it failed to acknowledge the values of wider English society (Cairns 1989), was seen as a significant triumph for Christian educationists, as it placed RI as the only statutory subject in the curriculum, building upon a wartime consensus regarding the nature of post-war reconstruction (Freathy 2008; Parker 2012). For Christian educationists, the religious clauses in the 1944 Education Act set the seal 'on more than twenty years of religious expansion in the schools' and, with the problem of interdenominational instruction seemingly solved, and with little appreciation of the distinction between church and state schools, they set about seeking to strengthen the Christian character of all schools to enable them to become vehicles of ‘Christian nurture’ (Hull 1975: 20-25).

\section{Part Five: Post-war developments}

\section{Re-visiting the nature and purpose of the journal}

The above presentation of the overarching philosophy of Christian education depicts an accord within the ICE, at least amongst its leading members, over the nature and purpose of religious education, and the professional standing of RI/RE teachers within this. Yet not all those involved in religious education were willing to think about their professional practice in such theoretical or theological terms. Nor did the structures created to advance the professionalisation of those concerned for religious education continue unchanged and unchallenged in the post-war era.

A fall in Religion in Education subscriptions from 4,470 in 1956 to 4,169 in 1957 when Basil Yeaxlee's time as editor ended, ${ }^{30}$ then again to 3,964 in $1959,{ }^{31}$ may suggest a gradual disillusionment with, or apathy about, the purposes of the journal at the time, and may 
provide a measure of the willingness of teachers to purchase professional knowledge in this medium. Prompted by alarm at such falling subscriptions, a questionnaire about its content and quality was distributed to around 70 prominent Christian educationists and members of the ICE. ${ }^{32}$ In the light of this, one senior member of the ICE maintained: 'Religion in Education is a review, and should not be allowed to degenerate into a magazine, offering rather slight articles of a superficial quality. It should provide teachers with something to get their teeth into, which will enrich their understanding' ${ }^{33}$ By 1961, driven by the economics of journal production and sales, and continued falling subscriptions, the Executive Committee of the ICE was forced to consider significant changes to Religion in Education. As it turned out, the Directors of SCM Press were equally concerned about the financial losses being made. On their behalf, David Edwards wrote to the ICE Executive with a plan for the future of Religion in Education, which would become more 'practical', have a wider appeal and be circulated six times a year, with a concomitant rise in cost to the ICE. ${ }^{34}$ Presented as a fait accompli, plans for the new journal were, by the time of his letter, clearly far advanced. The archival evidence suggests that Harold Loukes and Juliet Sladden had already been invited by Edwards to take on the roles of Editor and Assistant Editor respectively. At this stage, the new journal had the working title Living and Learning: a journal of Christian education.

Harold Loukes wrote to David Edwards, in February 1961, about his own ideas for a new magazine which would have changed the nature and function of the journal radically. To be entitled Living and Learning, it would be aimed 'at the sixth-former (16-18 year olds): adult in tone but avoiding airy allusions to the scholarship and experience that learned journals like to presuppose in their readers'. ${ }^{35}$ By the time of a meeting between the SCM Press, the ICE and the SCM in Schools, in April 1961, the realities of the situation had become clearer. Apart from mooting other titles, on behalf of the ICE (e.g. Christian Education and Christian Teaching Today) and by SCM Press (e.g. Learning to Live and the subtitle A Magazine of Religion in Education), final agreement came on $19^{\text {th }}$ May 1961 and in favour of the ICE's suggested title Learning for Living: a journal of Christian Education. ${ }^{36}$

The discussions associated with these proposals and changes highlight disagreements amongst Christian educationists concerning the nature and purpose of the journal. On one level, they are financial discussions about the marketability of different journal titles, functions and formats for teachers and other readers. On another level, they are about the quantity and type of professional knowledge that RI/RE teachers should be expected to 
acquire, and expose an unresolved tension between professional knowledge of a pure theoretical and applied practical nature.

\section{Re-organising religious education professionals}

By the mid-1960s, there was some disillusionment with the endeavours of the ICE characterised by what one correspondent, in a private letter to the Bishop of London, called 'the well-intentioned but frequently irrelevant attempts to put the R.I. period in order'. ${ }^{37}$ Citing the critiques of Harold Loukes (1961), and Ronald Goldman (1963), the anonymous correspondent argued that Christian educators had failed 'to develop the tremendous opportunities offered in the 1944 Education Act' and were 'quite unequal to the task' as demonstrated by the 'R.I. period', which is 'a dis-service in developing any true religious sense in the child' ${ }^{38}$ In contrast to those calling for Religion in Education to address a narrower practical remit, the correspondent argued that a 'larger vision' for religious education was now needed, and that this should be capable of answering questions, such as: 'How do the churches understand their fulfilment of Christian teaching as a shared concern of ordained men and teachers?'; 'What does it mean to be a Christian teacher in a State Education system?'; and 'What does Christianity have to say to young people about the nature of knowledge and certainty as related to belief?'. ${ }^{39}$ In the correspondent's view, a renewed 'campaign for Christian education' was needed in order 'to rescue the present

situation'. ${ }^{40}$ To this end, the correspondent supported the developments, which had begun in September 1962, towards the establishment of a separate Association for Christian Education, which would draw its membership from the ICE and the SCM in Schools. ${ }^{41}$

Driven it seems by economies of scale rather more than zeal to reform, the ICE and the SCM in Schools did merge in 1965 to create the Christian Education Movement (CEM) as an interdenominational organisation 'which the churches could back ecumenically'. ${ }^{42}$ Despite the change of organisational identity, and like its ecumenical and theologically-liberal predecessors, it became the leading organisation for English religious educators and the primary means by which teachers of RI/RE in non-denominational, state-maintained schools professionalised (Doney 2015). The CEM worked alongside the churches and LEAs to support the professional development of religious educators in schools, through its regional advisors, publications and courses, including residential conferences which 'offered support to lone specialist teachers in many schools' and 'functioned as social and pastoral events as well as in-service training' (Copley 2008: 87). Furthermore, according to Terence Copley 
(2008: 87), the 'CEM cultivated dialogue and good relations with other faiths and it was later to prove liberal enough to be prepared to publish multi-faith materials in its schools’ packs' (see also Doney 2015).

\section{Challenging professional organisational unity}

The CEM still faced the challenge of remaining representative of the breadth of perspectives amongst Christian educationalists concerned with RI/RE in non-denominational statemaintained schools, particularly in the changing cultural circumstances of the 1960s and 1970s. During the 1960s, when the aims and purposes of religious education in schools became increasingly challenged by secularists and humanists (Freathy \& Parker 2013; Doney 2015), as well as from educational researchers and teachers, the fragile unity that the CEM and its predecessors had worked hard to maintain, came under increasing pressure (Parker \& Freathy 2011a; Freathy \& Parker 2013). This is apparent in the debacle over the future of statutory RI and the standing of the Bible within it, which led to the founding of the National Association for Teachers of Religious Knowledge (NATORK) in 1967.

NATORK was founded by Dorothy C. Howlett, deputy-head at a Birmingham grammar school, rank-and-file member of the CEM, and an evangelical, both in her cause and in her Christianity. ${ }^{43}$ Initially a lobbying group in response to the Labour government's mooted new Education Act (Freathy \& Parker 2015), and in opposition to proposals from the National Secular Society and British Humanist Association to reform or abolish RI in schools (Freathy \& Parker 2013; Doney 2015), NATORK represented a schism from CEM. A flurry of letters from Howlett, record her call to the movement's hierarchy to respond more vigorously to the proposed Act until, finally, impatient with their seeming acquiescence, she arranged a public meeting at Birmingham Town Hall on the $29^{\text {th }}$ March 1968 to galvanise opposition.

NATORK, represented a conservative view of the nature and purpose of religious education, more dogmatically conservative in fact than the original vision of the ICE. This was clearly conveyed in the publicity leaflet for its public event, declaring NATORK to be the 'PEOPLE'S MOVEMENT in Religious Education'. It was established to 'DEFEND the existing arrangements for Religious Education as a whole in the curriculum of County Schools, which form most of the nation's schools' and to 'STAND BY the WORDING OF THE 1944 EDUCATION ACT, concerning WORSHIP and RELIGIOUS INSTRUCTION' which, it believed, accorded 'with the wishes of parents and teachers'. NATORK expressly 
wished 'to maintain the true religion of this country and its ancient faith in Jesus Christ'. 'We hope', it opined, 'the time will never come when, amongst all the books that are studied, the BIBLE ceases to be available to pupils, amongst all the topics that are studied the worship of GOD and the teaching of JESUS CHRIST is ignored, and when the great festivals, principally CHRISTMAS and EASTER go unrecognised'. ${ }^{44}$

The initial meeting at the Town Hall was not well attended, but the 'spirit, purpose and drive' displayed were remarked upon by leading figures within the CEM. ${ }^{45}$ Subsequent meetings of NATORK were noted for their fervour, where 'rousing sermons were delivered, stirring hymns sung and the Salvation Army Band going it fortissimo'. ${ }^{46}$ Such proselytising enthusiasm for the cause of religious education appeared from Howlett's point of view to be singularly lacking in the local CEM branch. This was perhaps indicative of the CEM's generally liberal and ecumenical ethos, serving denominational and non-denominational schools, but also resonant with the conception of RE teacher professionality that it promoted (Freathy et al 2014: 226). In contrast, NATORK claimed to be a 'people's movement', rather than 'a professional movement', seeking to maintain a distinctive and conservative Christian ethos for the subject, which was dissonant with the orientation of RI/RE in nondenominational, state-maintained schools.

Despite striking a chord amongst some, Howlett's cause was marginalized, being dismissed by members of the hierarchy of the CEM as irrelevant and 'unworthy'. In correspondence on the matter, she herself was variously described as 'rabid', 'a crackpot and a fanatic', a 'nit', 'round the bend' and 'just potty', especially by those CEM members who had initially shown sympathy with her cause, or were themselves alarmed by the prospect of legislative change. ${ }^{47}$ Although Howlett was committed to her cause, she was not politically shrewd. The disquiet caused by her '1944 Act fundamentalism' forced the CEM to assert its position as the society for teachers of RI/RE 'by virtue of our inheritance from the Institute of Christian Education'. ${ }^{48}$ Howlett's movement was more redolent of the original nineteenth-century evangelicalism out of which the movement for Christian education had grown than its 1960s liberal, ecumenical and professional progeny. At the heart of this furore were two contrasting orientations for the subject, and implicitly at least, two very different conceptions of the identity, role and responsibilities of RI/RE teachers. 
A decade later, in 1976, the Save Religion in State Schools (SRiSS) campaign was founded by the social activist and campaigner, Mary Whitehouse. Similar to Howlett’s NATORK, it interpreted any attack on religious education as 'an attack on England's historic faith in Jesus Christ ... and an attack on the monarchy as well'. ${ }^{49}$ Whitehouse's campaign also sought to preserve a social imaginary (Anderson 2006) which conceived of Britain as Christian. What each of these respective campaigns served to highlight is the moral panic that ensued in response to the secularist and humanist challenge to the nature and purpose of RI and subsequent initiatives to develop curricula containing multi-religious and secular content (Freathy \& Parker 2013). Both Howlett's and Whitehouse's campaigns were dismissed with equal impatience, and at the time failed to reverse the 'non-confessional' trends of development in the subject, but the perspectives to which they gave voice reverberated on (Rose 2003). In a changing cultural context, in the face of the growing religious and secular diversity of Britain and increasing challenges to the legitimacy and relevance of religious education, the interventions of Howlett and Whitehouse represented discord - albeit fleeting and little-known - about the nature and purpose of RI/RE in non-denominational, statemaintained schools. Despite being grassroots movements led by teachers, neither NATORK nor SRiSS were concerned to professionalise RI/RE, rather they sought to re-orientate the subject in an evangelically-Christian direction. Both initiatives were thwarted by discourses more dominant in the on-going cultural wars about the nature and purpose of RI/RE.

In this context, in the late 1960s and early 1970s, the parameters of the theological liberalism and ecumenical reach of the CEM's leadership was tested. Indeed, according to Terence Copley (2008: 106), the rise of open-ended, multi-faith and phenomenological RE 'coincided with the decline of the [CEM]'. The identity crisis from which it suffered was exacerbated by an increase in LEA advisory posts in RI/RE, some of which were filled by former CEM advisors. This had the concomitant effect of reducing the amount of income which the CEM derived from LEAs and supplanting the role of CEM Regional Advisors (Copley 2008: 106).

The rise of two other organisations is also worth mentioning in this context. First, in 1968, the Association of Religious Education (ARE) was established by Peter Lefroy-Owen, with its own regular bulletin, titled AREA, 'to express the religious independence and professionalism of teachers in the subject' (Copley 2008: 106). Having been seen as rivals, the CEM Teachers' Committee later merged, in 1985, to form the Professional Council for RE (PCfRE) which in turn became known as the National Association of Teachers of 
Religious Education (NATRE) from 2007 (Copley 2008: 106). It continues today as the principal subject association of RE professionals in primary and secondary schools in the United Kingdom, representing the professional interests of RE teachers through, for example, the establishment of special codes of conduct (NATRE/REC 2013). Second, in 1972, the CEM Teachers' Committee took the initiative, with the ARE, in sponsoring the founding of a Religious Education Council for England and Wales (REC). Such a body, they argued, could be more representative than CEM was able to be for a cross-section of RE teachers, and that a single federal body of this kind would have more authority. ${ }^{50}$ Established in 1973, the REC drew together member bodies representing not only RE teachers but also the main Christian denominations, other faith communities and humanists, and academic and professional associations involved in the study of religion. Still in existence, the broad constituency which the REC draws together demonstrates the political complexities surrounding religious education, and the multiple agendas and interest groups that need to be managed. This political complexity undoubtedly complicates the professionalisation of RE teachers not least because professional concerns have to be considered in the context of multiple others. Whether the professional voices of teachers are sufficiently prominent in such a polyphonic organisation is a moot point.

\section{Re-visiting the nature and purpose of the journal (again)}

In the midst of the (multi)cultural wars about the nature and purpose of RI/RE described above, thoughts turned once again to the title, function and format of the journal for religious educators. Successive editors of Learning for Living had been: Harold Loukes until 1964; David Ayerst, 1965-67; Catherine Fletcher, 1967-71; and John Hull, 1971-78. It was under the editorship of the latter that the journal was re-launched as the British Journal of Religious Education in 1978. This transition was a little less fraught than that from Religion in Education to Learning for Living in the previous decade, but it did not go without some forceful comment from readers. Driven again by the economics of the situation, the rising cost of paper and falling circulation figures, as early as 1970 the board of the SCM Press was forced to re-examine the nature of the publication. ${ }^{51}$ Disgruntlement about the character of Learning for Living was expressed by one reader, who described it as 'trendy and with it'. He went on:

... much of your thinking originates in the casual, open and 'liberal' attitudes of the 60s which seemed to me to have as much to do with the Christian faith as my cast-off Rugby boots discarded and rejected at much the same time as the permissive (sinful, immoral) society took all of us over and in. There are indisputable signs that these 
attitudes have so seriously failed the nation that it is doubtful if we can survive in any meaningful sense. One longs for the C.E.M. to stand up and be counted among the saints ... You are "good" - yes! You are moral - yes! You are liberal and humanist yes! But Christian? No, firmly no! Your last editorial is typical ... We expect from you direct and unswerving support for Christian religious education. Other religions are of peripheral and profound intellectual interest, but I have no duty or right under the law to teach anything other than the Christian faith. ${ }^{52}$

Commenting in the first edition of the British Journal of Religious Education upon expectations of the journal to peddle an unqualified Christian line, the then editor, John Hull, made clear what the renamed journal's orientation was:

Because it is published and provided by the Christian Education Movement (and not in spite of that fact, as the occasional reader misunderstands our position) we shall continue to promote an open, enquiring approach towards education in general and religious education in particular, in which the thoughtful views of Muslims, Hindus, Humanists, Christians and others will be presented. We are not a Christian forum. We are a forum provided by Christians for Christian reasons, in which all thoughtful people who share a concern for religions in education are invited to join. (Hull 1978: 1)

At the time of its new incarnation, Edward Robinson, of the Religious Experience Research Unit in Oxford, was able to recommend that Learning for Living's 'Sunday-school', 'dowdy' and two-column format, 'reminiscent of old Bibles', be lost in favour of smaller format of journal akin to the North American Religious Education. ${ }^{53}$

These changes in journal title, function and format serve as important markers, highlighting transitions in the shape of English religious education. Religion in Education generally addressed a national audience, as well as some readers in international missionary contexts. It discussed religious education in its broadest-sense, in terms of biblical and theological scholarship from a Christian perspective, primarily disseminating orientative knowledge, knowledge of the professional identities, roles and responsibilities of teachers, and subjectspecific content knowledge. By contrast, Learning for Living was predominantly concerned with RI, and subject-specific content knowledge and subject-specific pedagogical methods in particular, within a national and Christian frame of reference. However, just as it was necessary for ecumenical educationists and theologians in the early part of the twentieth century to develop a philosophy of Christian education that was not denominationally specific, so by the 1970s, new theories emerged to address the growing religious and secular diversity of Britain together with increasing reference to religious education research, policies and practices abroad (Parker \& Freathy 2011a; Freathy \& Parker 2013). This international 
perspective was evident in the founding of the International Seminar on Religious Education and Values in 1978, and by clearly distinguishing the British Journal of Religious Education from its international counterparts. In the years following, the international identity of the British Journal of Religious Education would be reinforced by, firstly, the growing pool of overseas readers and contributors, and secondly, the system used to assess the quality of research outputs in United Kingdom higher education institutions which favours publications with an international outlook and reach. Together these factors encouraged the publication of international and comparative research alongside that which focused on more parochial policies and practices. It may have gone some way towards the internationalisation of professional knowledge and (self-)understanding.

\section{Legacies}

The CEM remains an important stakeholder in English religious education. In 2001, it merged with the National Christian Education Council (formerly the Sunday School Union, est. 1803) to become Christian Education (CE). It continues to support the work of NATRE (as the professional organisation of RE teachers), and resources an advisory arm for schools, called RE Today services, directly engaging in the ongoing professional development of RE teachers. It publishes the British Journal of Religious Education (in association with the publishers, Taylor and Francis), the termly professional magazine RE Today, and teaching resources. CE continues to create and distribute professional knowledge. It works alongside other professional organisations within RE, including the National Association for Standing Advisory Councils on Religious Education, the Association of Religious Education Inspectors, Advisers and Consultants, and the Association of University Lecturers in Religion and Education. On the one hand the many organisations within RE signifies the ongoing vigour of the subject, on the other hand, arguably it disperses limited resources, perhaps indicating that the denominational divisions of earlier decades have been replaced by professional partitions which possibly impede the institutional and organisational systematisation and coordination of the thought and action upon which the further professionalisation of RE teachers depends.

\section{Part Six: Conclusion}

The history outlined above shows that RI/RE was intimately connected to other elements of the curriculum (e.g. worship) and the ethos permeating the life and work of schools for much of the period under consideration. Consequently, the curriculum subject of RI/RE was not 
always discrete and clearly delineated. Therefore, the study of the professionalisation of teachers of RI/RE in non-denominational, state-maintained schools, from c.1934 to c.1978, has to be undertaken within the broader context of religious education and the professionalisation of teachers generally. Calls to professionalise religious education have often focused on the application of a broader Christian philosophy concerning the influence of religious doctrines and concepts upon the nature and purpose of education and the nature of the child. In this context, 'religious education' was often used interchangeably, in a comprehensive and curricular sense, to refer respectively to (1) the religious nature of the educational process as a whole and through it the transmission of religious beliefs and values, and (2) instruction in religion in the form of a curriculum subject (see Bates 1976). The name and remit of the professional organisation, ICE, and the title of its journal, Religion in Education, reflect this broad vision and breadth of coverage. The subject-specific notion of the professionalisation of RI/RE teachers per se is therefore problematic in this early period; it was part of a more wide-ranging mission to professionalise all aspects of the educational process concerned with, and/or grounded in, religion. As the century progressed, RI/RE in a curricular sense in non-denominational, state-maintained schools would be differentiated increasingly from religious education in a comprehensive sense (Freathy 2005: 277; Parker 2015). Thereby, in such schools, it would become increasingly possible to conceive of RI/RE teachers as a distinct and specialised cadre of professional teachers, no longer orientated around a particular ecumenical Protestant Christian philosophy of education, but qualified by their advanced and differentiated knowledge, and exclusive standards of practical expertise, pertaining to the content and pedagogical methods associated with a specific curriculum subject. Although it is possible to conceive of RE teachers in this way, to do so without acknowledging evidence regarding the inadequate provision of suitably qualified RE teachers with appropriate levels of subject knowledge overlooks the dissonance between theory and practice.

This history has also shown that the denominational and interdenominational origins of the professionalisation of religious education ran deep. At the beginning of the period in question, leading representatives of the Christian churches, and national and international ecumenical movements, led the way in framing and defining the nature and character of religious education. The denominational origins formed the troubled backdrop from which $\mathrm{RI} / \mathrm{RE}$ in non-denominational, state-maintained schools emerged; the interdenominational origins paved the way for its professionalisation. The ICE provided an organisational 
structure for cohering and developing the profession, and Religion in Education provided the means for defining and disseminating professional knowledge. By the end of the period, however, notions of RE teaching and teacher professionality in non-denominational schools were becoming increasingly divorced from direct religious purpose and intent. Even so, from the 1970s to the present, the churches and religious communities continued to play a leading role through such bodies as the CE and the REC, as well as through local statutory processes. However much may be attributed to the churches, and interdenominational institutions and organisations, in laying the foundations for the professionalisation of teachers of RI/RE in our focus period, it is questionable whether further professionalisation can occur without RE teachers playing a more substantial role in the area they profess by: organising themselves; representing their own professional interests; determining their own professional knowledge, standards and expertise; and shaping professional development provision. Whilst they are unlikely as an occupational group to attain high social prestige and high economic rewards, they can aspire to advance these other classical characteristics of professionalism, balancing their autonomy with corporate responsibility towards the multiple stakeholders who share their educational and societal concerns. 
Appendix: Table 3

\begin{tabular}{|c|c|c|c|c|c|c|}
\hline Name & Dates & $\begin{array}{l}\text { University } \\
\text { Education }\end{array}$ & Clerical office & Missionary/ecumenical activity & Educational appointments & Other roles/responsibilities \\
\hline $\begin{array}{l}\text { Sir Henry } \\
\text { Hadow } \\
\text { (Shera, } \\
\text { 2004) }\end{array}$ & $\begin{array}{c}1859- \\
1937\end{array}$ & $\begin{array}{l}\text { Worcester } \\
\text { College, } \\
\text { Oxford }\end{array}$ & & & $\begin{array}{l}\text { - Lecturer, Fellow, Tutor and Dean, } \\
\text { Worcester College, Oxford (1878-89) } \\
\text { - Principal, Armstrong College, } \\
\text { Newcastle-upon-Tyne (1909) } \\
\text { - Vice-Chancellor, Durham University } \\
\text { (1916) } \\
\text { - Vice-Chancellor, Sheffield University } \\
\text { (1919-30) } \\
\text { - Chair of four Board of Education } \\
\text { Consultative Committees (1920-34) }\end{array}$ & $\begin{array}{l}\text { - Chair of Archbishop's Commission on } \\
\text { Religious Education (1924-29) } \\
\text { - President, Association for Teachers of } \\
\text { Religious Knowledge (1932-37) }\end{array}$ \\
\hline $\begin{array}{l}\text { John } \\
\text { Scott Lidgett } \\
\text { (Wellings, } \\
\text { 2012) }\end{array}$ & $\begin{array}{l}1854- \\
1953\end{array}$ & $\begin{array}{l}\text { University } \\
\text { College, } \\
\text { London }\end{array}$ & $\begin{array}{l}\text { - Wesleyan Methodist } \\
\text { Minister (1876) } \\
\text { - Founder Wesleyan } \\
\text { Bermondsey Settlement } \\
\text { (1891) }\end{array}$ & & & 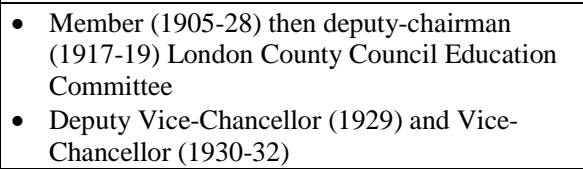 \\
\hline $\begin{array}{l}\text { Arthur } \\
\text { Mayhew } \\
\text { (Whitehead, } \\
\text { 2004) }\end{array}$ & $\begin{array}{c}1878- \\
1948\end{array}$ & $\begin{array}{l}\text { New } \\
\text { College, } \\
\text { Oxford }\end{array}$ & & & $\begin{array}{l}\text { - Indian Education Service (1903): School } \\
\text { Inspector; Deputy Director of Public } \\
\text { Instruction; Inspector of European and } \\
\text { Teacher-training Schools; and Director } \\
\text { of Public Instruction in the Central } \\
\text { Provinces } \\
\text { - President, Indian Central Advisory } \\
\text { Board of Education (1922) }\end{array}$ & $\begin{array}{l}\text { - Joint Secretary of the Colonial Office Advisory } \\
\text { Committee on Education in the Colonies } \\
\text { (1929) } \\
\text { - Leading expert on colonial education }\end{array}$ \\
\hline $\begin{array}{l}\text { Winifred } \\
\text { Mercier } \\
\text { (Bryant, } \\
\text { 2004) }\end{array}$ & $\begin{array}{c}1878- \\
1934\end{array}$ & $\begin{array}{l}\text { Somerville } \\
\text { College, } \\
\text { Oxford }\end{array}$ & & & $\begin{array}{ll}\text { - } & \text { Teacher, Manchester High School for } \\
& \text { Girls (1907-09) } \\
\text { - } & \text { Director of Studies and Lecturer, Girton } \\
\text { - College, Cambridge (1909-13) } \\
\text { - Vice-Principal, Leeds Municipal } \\
\text { Training College (1913-16) } \\
\text { - Principal, Whitelands College (Anglican } \\
\text { teacher training college) (1918) } \\
\end{array}$ & $\begin{array}{l}\text { - Member of committee producing The } \\
\text { Cambridgeshire Syllabus of Religious } \\
\text { Teaching for Schools (1924) } \\
\text { - Member of Archbishop's Commission on } \\
\text { Religious Education }\end{array}$ \\
\hline $\begin{array}{l}\text { Sir Walter } \\
\text { Moberly } \\
\text { (Grimley, } \\
\text { 2004b) }\end{array}$ & $\begin{array}{c}1881- \\
1974\end{array}$ & $\begin{array}{l}\text { New } \\
\text { College, } \\
\text { Oxford }\end{array}$ & - Active Anglican & & $\begin{array}{l}\text { - Professor, University of Birmingham } \\
\text { (1921) } \\
\text { - Principal, University College, Exeter } \\
\text { (1924) } \\
\text { - Vice-Chancellor, Manchester University } \\
\text { (1926) } \\
\text { - President, University Grants Committee } \\
(1934)\end{array}$ & $\begin{array}{l}\text { - Authored, The Crisis in the University (1949). } \\
\text { - First Principal, St Catharine's, Cumberland } \\
\text { Lodge (1949-55) }\end{array}$ \\
\hline
\end{tabular}




\begin{tabular}{|c|c|c|c|c|c|c|}
\hline $\begin{array}{l}\text { Joseph } \\
\text { Houldsworth } \\
\text { Oldham } \\
\text { (Bliss, 2007) }\end{array}$ & $\begin{array}{l}1874- \\
1969\end{array}$ & $\begin{array}{l}\text { - Trinity } \\
\text { College, } \\
\text { Oxford } \\
\text { - University } \\
\text { of Halle, } \\
\text { Germany }\end{array}$ & & $\begin{array}{l}\text { Missionary, India (Scottish } \\
\text { Young Man’s Christian } \\
\text { Association) (1897-1900) } \\
\text { - Secretary, World Missionary } \\
\text { Conference, Edinburgh } \\
\text { (1910) } \\
\text { - Secretary, International } \\
\text { Missionary Council (1921-38) } \\
\end{array}$ & & 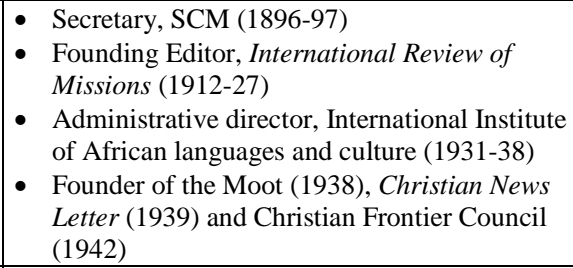 \\
\hline $\begin{array}{l}\text { Eleanor } \\
\text { Addison } \\
\text { Phillips }\end{array}$ & $\begin{array}{l}1874- \\
1952\end{array}$ & $\begin{array}{l}\text { St Hugh’s } \\
\text { College, } \\
\text { Oxford }\end{array}$ & & & $\begin{array}{ll}\text { - } & \text { Headmistress, Clifton High School for } \\
\text { Girls (1908-33) } \\
\text { - President of the Association of } \\
\text { Headmistresses (1929-31) }\end{array}$ & \\
\hline $\begin{array}{l}\text { Oliver Quick } \\
\text { (Chapman, } \\
\text { 2004) }\end{array}$ & $\begin{array}{c}1885- \\
1944\end{array}$ & $\begin{array}{l}\text { Corpus } \\
\text { Christi } \\
\text { College, } \\
\text { Oxford }\end{array}$ & $\begin{array}{l}\text { - Anglican Deacon (1911) } \\
\text { and Priest (1913) } \\
\text { - Canon, St Paul’s Cathedral } \\
\text { (1930) }\end{array}$ & $\begin{array}{ll}\text { - } & \text { International Missionary } \\
& \text { Conference, Jerusalem (1928) } \\
\text { - } & \text { Faith and Order Conference, } \\
\text { Lausanne (1927) } \\
\text { - Faith and Order Conference, } \\
\text { Edinburgh (1937) } \\
\end{array}$ & $\begin{array}{l}\text { - Professorship and Canonry at Durham } \\
\text { University and Cathedral (1934) } \\
\text { - Regius Professor of Divinity and Canon } \\
\text { of Christ Church, Oxford (1939) }\end{array}$ & $\begin{array}{l}\text { - Published numerous influential theological } \\
\text { works }\end{array}$ \\
\hline $\begin{array}{l}\text { Tissington } \\
\text { Tatlow } \\
\text { (Martin, } \\
\text { 2004) }\end{array}$ & $\begin{array}{l}1876- \\
1957\end{array}$ & $\begin{array}{l}\text { Trinity } \\
\text { College, } \\
\text { Dublin }\end{array}$ & $\begin{array}{ll}\text { - } & \text { Anglican Deacon (1902) } \\
& \text { and Priest (1904) } \\
\text { - } & \text { Curate (St Barnabas, } \\
& \text { Kensington) (1902) } \\
\text { - } & \text { Rector (All Hallows, } \\
& \text { Lombard St, London) } \\
\text { (1926) } \\
\text { - } \\
\text { Rector (St Edmund King } \\
\text { and Martyr) (1937) }\end{array}$ & $\begin{array}{l}\text { - World Missionary Conference, } \\
\text { Edinburgh (1910) } \\
\text { - Honorary Secretary, Faith and } \\
\text { Order Conference, Lausanne } \\
\text { (1927) } \\
\text { - European Treasurer, Faith and } \\
\text { Order Movement } \\
\text { - A chief architect of British } \\
\text { Council of Churches }\end{array}$ & & $\begin{array}{ll}\text { - } & \text { Honorary Director, ICE } \\
\text { - Secretary, Student Volunteer Missionary } \\
\text { Union (1897) } \\
\text { - Secretary, British College Christian Union } \\
\text { (1898) (renamed SCM) } \\
\text { - } \text { General Secretary, SCM (1903-29) }\end{array}$ \\
\hline
\end{tabular}




\begin{tabular}{|c|c|c|c|c|c|c|}
\hline $\begin{array}{l}\text { William } \\
\text { Temple } \\
\text { (Hastings, } \\
\text { 2004) }\end{array}$ & $\begin{array}{c}1881- \\
1944\end{array}$ & $\begin{array}{l}\text { Balliol } \\
\text { College, } \\
\text { Oxford }\end{array}$ & 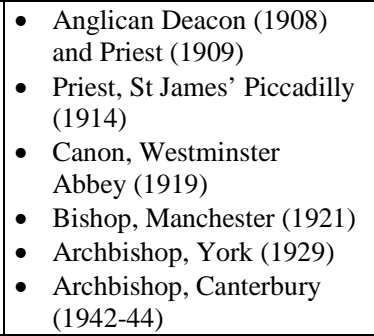 & $\begin{array}{l}\text { - International Missionary } \\
\text { Conference steward, } \\
\text { Edinburgh (1910) }\end{array}$ & $\begin{array}{l}\text { - Lecturer, Queen’s College, Oxford } \\
\text { (1904-10) } \\
\text { - Headmaster, Repton School (1910-14) }\end{array}$ & - SCM member \\
\hline $\begin{array}{l}\text { William } \\
\text { Wyamar } \\
\text { Vaughan } \\
\text { (Bradby, } \\
\text { 2004) }\end{array}$ & $\begin{array}{c}1865- \\
1938\end{array}$ & $\begin{array}{l}\text { New } \\
\text { College, } \\
\text { Oxford }\end{array}$ & & & 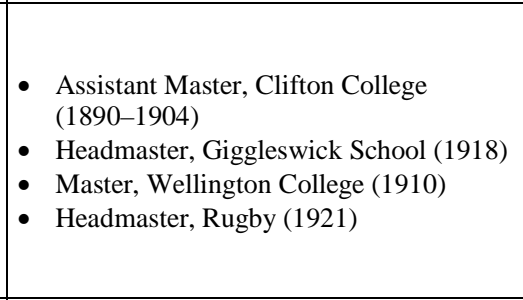 & $\begin{array}{l}\text { - President/Chair of numerous educational } \\
\text { organisations e.g. Incorporated Association of } \\
\text { Headmasters (1916), Educational Section of } \\
\text { British Association (1925), and Central } \\
\text { Council for School Broadcasting (1935) } \\
\text { - Board of Education Consultative Committee } \\
\text { (1920-26) } \\
\text { - Visited Gold Coast for Advisory Committee on } \\
\text { Education in the Colonies }\end{array}$ \\
\hline $\begin{array}{l}\text { Basil } \\
\text { Yeaxlee } \\
\text { (Marriott, } \\
\text { 2004) }\end{array}$ & $\begin{array}{l}1883- \\
1967\end{array}$ & $\begin{array}{l}\text { Mansfield } \\
\text { College, } \\
\text { Oxford }\end{array}$ & - Congregationalist Minister & & $\begin{array}{l}\text { - Principal, Westhill College (1930-1935) } \\
\text { - } \text { Reader and Lecturer, University of } \\
\text { Oxford (1935-49) } \\
\text { - Librarian and Tutor, Mansfield College, } \\
\text { Oxford (1935-49) }\end{array}$ & $\begin{array}{ll}\text { - } & \text { Editor, New Chronicle of Christian Education } \\
\text { (1928-30) } \\
\text { - First Editor, Religion in Education (1934), then } \\
\text { Book Reviews Editor (1957-67) } \\
\text { - } \begin{array}{l}\text { Member of the Free Church Federal Council } \\
\text { Education Committee }\end{array}\end{array}$ \\
\hline
\end{tabular}




\section{References}

All Party Parliamentary Group. (2013) RE: The Truth Unmasked. The supply of and support for Religious Education teachers. An Inquiry by the All Party Parliamentary Group on Religious Education. Available online at: http://www.recouncil.org.uk/images/stories/pdf/APPG_RE_The_Truth_Unmasked.pdf (access 22 June 2015).

Anderson, B. (2006 edn.) Imagined Communities: reflections on the origin and spread of nationalism (London, Verso).

Ball, S. J. (1985) English for the English since 1906, In: I. Goodson (Ed.) Social Histories of the Secondary Curriculum: subjects for study (London: Falmer).

Bates, D. J. (1976) The Nature and Place of Religion in English State Education c1900c1944 with Special Reference to Conceptions of the relations of Religion to Education and the development of Christian Education c1920-c1944 (Unpublished Ph.D. Thesis, University of Lancaster).

Becher, T. \& Trowler, P. R. (2001) Academic Tribes and Territories (Buckingham, Open University Press).

Behenna, M. (2001) The Significance of Canon E. F. Hall as General Secretary of the National Society in the negotiations between the Church of England and the government on the clauses of the 1944 Education Act concerning denominational Religious Education and Church Schools (M.Phil. Thesis, University of Exeter).

Bliss, K. [revised by Andrew Porter] (2007) Oldham, Joseph Houldsworth (1874-1969). Oxford Dictionary of National Biography (Oxford, Oxford University Press) [http://www.oxforddnb.com/view/article/35301, accessed 11th February 2012].

Bradby, H. C. [revised by M. C. Curthoys] (2004) Vaughan, William Wyamar (1865-1938). Oxford Dictionary of National Biography (Oxford, Oxford University Press) [http://www.oxforddnb.com/view/article/36635, accessed 16th March 2012]

Bryant, M. (2004) Mercier, Winifred Louise (1878-1934). Oxford Dictionary of National Biography (Oxford, Oxford University Press) [http://www.oxforddnb.com/view/article/48685, accessed $16^{\text {th }}$ March 2012].

Cairns, J. M. (1989) Religious Education and the 1944 Education Act: missed opportunities, in: E. Cox \& J. M. Cairns (Eds) Reforming Religious Education: the religious clauses of the 1988 Education Reform Act (London, Institute of Education).

Chadwick, P. (1997) Shifting Alliances: Church and State in English Education (London, Cassell).

Chapman, M. D. (2004) Quick, Oliver Chase (1885-1944). Oxford Dictionary of National Biography (Oxford, Oxford University Press) [http://www.oxforddnb.com/view/article/35639, accessed 16th March 2012].

Chorley, G. F. (1984) The Work of Basil Yeaxlee, British Journal of Religious Education, 6(2), 62-67.

Clarke, C. \& Woodhead, L. (2015) A New Settlement: religion and beliefs in schools, (Lancaster, Westminster Faith Debates).

Cliff, P. B. (1986) The Rise and Development of the Sunday School Movement in England, 1780-1980 (Cambridge, National Christian Education Council): 233-236.

Committee of Enquiry upon the Army and Religion: The Army and Religion: An enquiry and its bearing upon the religious life of the nation (London, Macmillan, 1919).

Conference on Christian Politics, Economics and Citizenship. (1924) The proceedings of C.O.P.E.C.: being a report of the meetings of the Conference on Christian Politics, Economics and Citizenship, held in Birmingham, April 5-12, 1924 (London, Longmans Green). 
Conroy, J., Lundie, D., Davis, R. A., Baumfield, V., Barnes, L. P., Gallagher, T., Lowden, K., Bourque, N., \& Wenell, K. (2013) Does Religious Education work? A multidimensional investigation (London, Bloomsbury Press).

Copley, T. (1998) Rediscovering the Past: Writings on Religious Education in Religion in Education Quarterly, 1934-39, Raises Some Questions for Today's Religious Educators, British Journal of Religious Education, 20(2), 82.

Copley, T. (2002) Black Tom Arnold of Rugby: The Man and The Myth (London: Continuum).

Copley, T. (2008) Teaching Religion (Exeter, Exeter University Press).

Cruickshank, M. (1963) Church and State in English Education: 1870 to the Present Day (London, Macmillan).

Department for Education. 2015. Get Into Teaching: Bursaries and Funding. http://www.education.gov.uk/get-into-teaching/funding/postgraduate-funding. [Accessed 15 May 2015].

Doney, J (2015) 'That would be an ecumenical matter' Contextualizing the Adoption of the Study of World Religions in English Religious Education Using 'Statement Archaeology', a Systematic Operationalization of Foucault's Historical Method. (Unpublished PhD thesis, University of Exeter).

Edwards, D. (1971) Leaders of the Church of England 1828-1944 (London, Oxford University Press).

Evetts, J. (2003) The Sociological Analysis of Professionalism: Occupational Change in the Modern World, International Sociology, 18, 395-415.

Flindall, R. P. (1972) The Church of England 1815-1948 (London, SPCK).

Freathy, R. J. K. (2005) Religious Education and Education for Citizenship in English Schools, 1934-1944 (Unpublished Ph.D. Thesis, University of Exeter)

Freathy, R. J. K. (2007) Ecclesiastical and religious factors which preserved Christian and traditional forms of education for citizenship in English schools, 1934-1944, Oxford Review of Education, 33(3), 367-377.

Freathy, R. (2008a) The Triumph of Religious Education for Citizenship in English Schools, 1935-1949, History of Education, 37(2), 295-316.

Freathy, R. J. K. (2008b) Three Perspectives on Religious Education and Education for Citizenship in English Schools, 1934-1944, British Journal of Religious Education, 30(2), 103-112.

Freathy, R. \& Parker, S. G. (2010) The necessity of historical inquiry in educational research: The case of Religious Education, British Journal of Religious Education, 32(3), 229-243.

Freathy, R. \& Parker, S. (2012) Freedom from Religious Beliefs: Humanists and Religious Education in England in the 1960s and 1970s. In S. Parker, R. Freathy and L.J. Francis (Eds) Religious Education and Freedom of Religion and Belief (Oxford, Peter Lang).

Freathy, R. \& Parker, S. (2013) Secularists, Humanists and Religious Education: Religious crisis and curriculum change in England, 1963-1975, History of Education, 42(2), 222-256.

Freathy, R. \& Parker, S. G. (2015) Prospects and Problems for Religious Education in England, 1967-1970: curriculum reform in political context, Journal of Beliefs and Values, 36(1), 5-30.

Freathy, R., Parker, S. G. \& Doney, J. (2015) Raiders of the Lost Archives: Searching for the Hidden History of Religious Education in England, in: S. G. Parker, R. Freathy \& L. J. Francis (Eds) History, Remembrance and Religious Education (Oxford, Peter Lang).

Freathy, R., Parker, S., Schweitzer, F., \& Simojoki, H. (2014) Towards international comparative research on the professionalization of Religious Education, Journal of Beliefs and Values, 35 (2), 225-241. 
Freathy, R., Parker, S., Schweitzer, F. and Simojoki, H. (2016). Conceptualizing and Researching the Professionalization of Religious Education Teachers: Historical and International Perspectives. British Journal of Religious Education 38(2) [forthcoming].

Freidson, E. (1994) Professionalism Reborn: Theory, Prophecy and Policy (Cambridge, Polity Press).

Goldman, R. (1963) The development of religious thinking, Learning for Living, 2(5), 6-9.

Goodlad, S. (1984) Education for the Professions. Quis Custodat...? (London, SRHE/NFER-Nelson).

Green, S. J. D. (2011) The Passing of Protestant England: secularisation and social change c.1920-1960 (Cambridge: CUP).

Grimley, M. (2004a) Citizenship, Community and the Church of England: liberal Anglican theories of the state between the wars (Oxford, Clarendon).

Grimley, M. (2004b) Moberly, Sir Walter Hamilton (1881-1974). Oxford Dictionary of National Biography (Oxford, Oxford University Press) [http://www.oxforddnb.com/view/article/31451, accessed 16th March 2012].

Grimley, M. (2007) The Religion of Englishness: Puritanism, Providentialism, and 'National Character’, 1918-1945, North American Journal of British Studies, 46(4), 884-906.

Gwyer, B. E. (1934) Christian Education at Home and Oversees: the second Swanwick conference, Religion in Education, 1(3), 166.

Handford, B. W. T. (1937) "Revolutionizing” our New Testament Teaching, Religion in Education, 4(2), 88-94.

Hastings, A. (1991) A History of English Christianity: 1920-1990 (London, SCM Press).

Hastings, A. (2004) Temple, William (1881-1944). Oxford Dictionary of National Biography (Oxford, Oxford University Press) [http://www.oxforddnb.com/view/article/36454, accessed 11th February 2012].

Heater, D. (1990) Citizenship: The Civic Ideal in World History, Politics and Education (London, Longman).

Horn, K. (2016) Profession, Professionalization, Professionality, Professionalism Historical and Systematic Remarks Using the Example of German Teacher Education, British Journal of Religious Education.

Hull, J. (1975) School Worship: an obituary (London, SCM Press).

Hull, J. (1978) Editorial, British Journal of Religious Education, 1(1), 1-2.

Irwin, Lord (Edward Wood) (1934) Education and Religion, Religion in Education, 1(1), 5.

Kunter, M., Baumert, J., Blum, W., Klusmann, U., Krauss, S. \& Neubrand, M. (Eds) (2011) Professionelle Kompetenz von Lehrkräften. Ergebnisse des Forschungsprogramms COACTIV (Münster et al., Waxmann).

Leeson, S. (1948) The Public Schools Question (London, Longmans Green).

Louis, P. (1985) Anglican Attitudes to the Relationship between the church and education with particular reference to the thoughts of William Temple, Spencer Leeson, Robert Stopford and Robert Waddington (Unpublished M.Phil. Thesis, University of Manchester).

Loukes, H. (1961) Teenage Religion: an enquiry into attitudes and possibilities among British boys and girls in Secondary Modern Schools (London, SCM Press).

McClelland, C. E. (1991) The German experience of professionalization: Modern learned professions and their organizations from the early nineteenth century to the Hitler era (Cambridge et al., Cambridge University Press).

Macdonald, K. M. (1995) The Sociology of the Professions (London, Sage).

Machin, G. I. T. (1998) Churches and Social Issues in Twentieth-Century Britain (Oxford, Clarendon), 32-33. 
Marriott, S. (2004) Yeaxlee, Basil Alfred (1883-1967). Oxford Dictionary of National Biography (Oxford, Oxford University Press) [http://www.oxforddnb.com/view/article/63843, accessed 16th March 2012].

Martin, H. (2004) Tatlow, Tissington (1876-1957). Oxford Dictionary of National Biography (Oxford, Oxford University Press) [http://www.oxforddnb.com/view/article/36422, accessed 13th January 2012].

Matthews, C. H. S. (1934) The ATRK Conference, Religion in Education, 1(2), 101-107.

Michell, C. (1984) Some Themes in Christian Education c.1935-60, British Journal of Religious Education, 6(2), 82-87.

Michell, C. (1985) Christian Education and the Christian Nation: a study of the role envisaged for religious education in British State Schools c.1920-1965 (Unpublished M. Litt. Thesis, University of Cambridge).

Mitchell, W. F. (1937) The New German Religion and its Implications for Religious Education, Religion in Education, 4(1), 22-29.

Murphy, J. (1971) Church, State and Schools in Britain, 1800-1970 (London, Routledge).

National Association of Teachers of Religious Education and Religious Education Council for England and Wales. 2013. DFE Teacher standards 2013: An RE exemplification. http://www.natre.org.uk/uploads/Free\%20Resources/DFE\%20Teacher\%20standards\%20201

3.pdf [Accessed 15 May 2015].

OFSTED (2012) Religious Education: Raising the potential (London, OFSTED).

Oliver, J. (1968) The Church and Social Order (Oxford, Mowbray).

Orchard, J. \& Whately, H. (2013) Practical wisdom and the good RE teacher: A case for change to Secondary ITT in RE in England (Oxford, Culham St Gabriel's).

Parker, S. G. (2005) Faith on the Home Front: aspects of church life and popular religion in Birmingham, 1939-1945 (Oxford, Peter Lang).

Parker, S. (2012) Reinvigorating Christian Britain: the spiritual opportunities of the war, national identity, and the hope for religious education, in: S. G. Parker \& T. Lawson (Eds) God and War: the Church of England and Armed Conflict in the Twentieth-century (Aldershot, Ashgate), 61-79.

Parker, S. G. (2015) Mediatising childhood religion: the BBC, John G. Williams and collective worship for schools in England, 1940-1975, Paedagogica Historica: International Journal of the History of Education, 51(5), 614-630.

Parker, S. G. \& Freathy, R. J. K. (2011a) Ethnic diversity, Christian hegemony and the emergence of multi-faith Religious Education in the 1970s, History of Education, 41(3), 381404.

Parker, S. G. \& Freathy, R. J. K. (2011b) Context, complexity and contestation: Birmingham's Agreed Syllabuses for Religious Education since the 1970s, Journal of Beliefs and Values, 32(2), 247-262.

Priestley, J. (2002) Westhill College: The Embodiment of a Religious and Educational Ideal, Panorama: International Journal of Comparative Religious Education and Values, 14(2), 169-184.

Priestley, J. (2007) The Lumber Merchant and the Chocolate King: The Contributions of George Hamilton Archibald and George Cadbury to the Sunday School Movement in England and Wales, in: S. Orchard \& J. H. Y. Briggs (Eds) The Sunday Movement: Studies in the Growth and Decline of Sunday Schools (Milton Keynes, Paternoster).

Raftery, D. (2012) Religions and the history of education: a historiography, History of Education, 41(1), 41-56.

Reeves, M. (Ed.) (1999) Christian Thinking and Social Order (London, Cassell).

Religious Education Council of England and Wales. (2013) A review of Religious Education in England (London, REC). 
Roberts, S \& Parker, S.G. (in progress) A Transnational Endeavour to Reform Sunday Schooling: George Hamilton Archibald and the Westhill circle, 1907-39, Journal of Religious History.

Rose, D. (2003) The voice of the cultural restorationists: recent trends in RE policy-making, Curriculum Journal, 14(3), 305-326.

Shattock, M. (2014) Can we still speak of their being an academic profession?, History of Education, 43(6), 727-739.

Shera, F. H. [revised by David J. Golby] (2004) Hadow, Sir (William) Henry (1859-1937). Oxford Dictionary of National Biography (Oxford, Oxford University Press) [http://www.oxforddnb.com/view/article/33631, accessed 16th March 2012].

Simon, B. (1981) Why no pedagogy in England?, in: B. Simon \& W. Taylor (Eds) Education in the eighties: the central issues (London, Batsford), 124-145.

Sutcliffe, J. M. (1984) The Movement and the Journal: Some Historical Reflections, British Journal of Religious Education, 6(2), 58.

Teach: RE. 2015. RE Teaching: Beyond the Ordinary. http://www.teachre.co.uk/beyondtheordinary/ [Accessed 15 May 2015]

Temple, W. (1936) Teachers and the Need of Our Time, Religion in Education, 3(4), 181-83. Wellings, M. (2004) Lidgett, John Scott (1854-1953), Oxford Dictionary of National Biography (Oxford: Oxford University 2004 [http://www.oxforddnb.com/view/article/34530, accessed 16th March 2012].

Whitehead, C. (2004) Mayhew, Arthur Innes (1878-1948). Oxford Dictionary of National Biography (Oxford, Oxford University Press) [http://www.oxforddnb.com/view/article/63828, accessed 16th March 2012].

World Missionary Conference. (1919) Report of Commission III, Education in Relation to the Christianization of National Life (Edinburgh and London, Oliphant, Anderson \& Ferrier).

Yeaxlee, B. (1934a) Our aim, Religion in Education, 1(1), 1-3.

Yeaxlee, B. (1934b) Madam How and Lady Why, Religion in Education, 1(2), 61-62.

Yeaxlee, B. (1934c) How Teachers May Equip Themselves, Religion in Education, 1(4), 190-196.

Yeaxlee, B. (1935a) A spirit made perfect, Religion in Education, 2(1), 1-2.

Yeaxlee, B. (1935b) The realms of gold, Religion in Education, 2(3), 121-122.

Yeaxlee, B. (1935c) Imaginative interpretation, Religion in Education, 2(4), 181-182.

Yeaxlee, B. (1936a) Facts and meanings, Religion in Education, 3(1), 1-2.

Yeaxlee, B. (1936b) The call for specialists, Religion in Education, 3(2), 61-62.

Yeaxlee, B. (1936c) How much of the Old Testament should we teach?, Religion in Education, 3(3), 121-122.

Yeaxlee, B. (1937a) From one quarter to another, Religion in Education, 4(1), 1-2.

Yeaxlee, B. (1937b) The risks of teaching Scripture, Religion in Education, 4(2), 61-62.

Yeaxlee, B. (1937c) Immediate tasks, Religion in Education, 4(4), 181-2.

Yeaxlee, B. (1940) Liberties and Values, Religion in Education, 7(2), 62.

Yeaxlee, B. (1941a) Reconstruction and religious education, Religion in Education, 8(2), 4550 .

Yeaxlee, B. (1941b) The Christian prospect in education, Religion in Education, 8(4), 133135.

\section{Notes on the contributors}

Stephen Parker is Professor of the History of Religion and Education at the University of Worcester. He has authored and edited numerous books, book chapters and journal articles on 
the histories of religion and education and their intersections, including God and War: the Church of England and Armed Conflict in the Twentieth Century (Aldershot, 2012) and History, Remembrance and Religious Education (Oxford, 2014). He is Assistant Editor and Reviews Editor for the Journal of Beliefs and Values, and lead Editor for the Peter Lang series on Religion, Education and Values. He is currently directing a Leverhulme Trustfunded project on religious educational broadcasting.

Rob Freathy is Associate Professor in History of Education at the University of Exeter. He has authored and edited numerous books, book chapters and journal articles, presenting both historical and contemporary perspectives on religious education. These include, most recently, History, Remembrance and Religious Education (Oxford, 2014), and the textbook, The Art of Bible Reading (Buxhall, 2014). He is Book Reviews Editor for History of Education, co-editor of History of Education Researcher, an Editorial Board member for the British Journal of Religious Education, and an editor of the Peter Lang series on Religion, Education and Values.

Jonathan Doney is a Research Fellow at the University of Exeter. His first degree was in Theological Studies (Bristol), and his Masters is in Educational Research (Exeter). His doctoral work, funded by the ESRC and supervised by Drs Rob Freathy and Deborah Osberg, centred on the relationships between the Ecumenical movement and historical developments in English RE during the 1960s and 1970s. His wider research interests are in methodological innovation, critical studies, and the role of education in developing identity. He is co-editor of History of Education Researcher.

\footnotetext{
${ }^{1}$ Elementary Education Act, 1870, 33 \& 34 VICT, chapter 75, section 7 [1].

${ }^{2}$ Elementary Education Act, 1870, section 7 [2].

${ }^{3}$ Elementary Education Act, 1870, section 14[2].

${ }^{4}$ The 1870 Elementary Education Act made the provision of education for all children between 5 and 13 years of age a legal duty, and established a series of local School Boards who were required to ensure that sufficient schools were available (Great Britain, The Elementary Education Act, 33 \& 34, Vict. c. 75, (1870)). The Act also authorised these School Boards to pass local laws making attendance compulsory, but only if they so chose (Great Britain, The Elementary Education Act, 33 \& 34, Vict. c. 75, (1870), Section 74.), although it was not until 1880 that school attendance became uniformly compulsory (Great Britain, The Elementary Education Act, $43 \& 44$, Vict. c. 23, (1880)). It was a further ten years before the cost of elementary education was met by the state with a per capita grant of ten shillings per year (Great Britain, The Elementary Education Act, 54 \& 55, Vict. c. 56, (1891)); prior to this parents had been liable to a charge, although a number of exemptions were in place, especially for those with low incomes (Great Britain, The Elementary Education Act, 33 \& 34, Vict. c. 75, (1870)).

${ }^{5} 1902$ Education Act. 2 Edw. 7. Cap 42. Part IV. General. Section 18. and Part III. Elementary Education. Section 6.

${ }^{6}$ Westhill College became a strategic partner of the University of Birmingham in the late 1990s, was closed as a College of Higher Education in 2001, many of its staff being moved into departments at Birmingham.

${ }^{7}$ By 1930 eight local authorities had adopted an agreed syllabus, Nottinghamshire, Cambridgeshire, the West Riding of Yorkshire, Surrey, Oxfordshire, Lancashire and Cumberland, Westmoreland and Carlisle.

${ }^{8}$ Bates (1976: 90) states that 58 LEAs adopted the Cambridgeshire Agreed Syllabus and 12 more used the Cambridgeshire syllabus in conjunction with other syllabuses; 15 LEAs adopted the West Riding Agreed Syllabus and 5 more used it in conjunction with other syllabuses; 14 LEAs adopted the Hampshire and Wiltshire Agreed Syllabus and 5 more used it in conjunction with other syllabuses, and 11 LEAs adopted Macmillan's Agreed Syllabus.
} 
${ }^{9}$ Mr. A. Burrell (Formerly Principal of the Borough Road Training College); Rev. S. Chadwick (Principal of Cliff College, Sheffield and President of the National Free Church Council); Miss Hetty Lee (Organiser in Religious Teaching to the National Society); Professor A. S. Peake (Rylands Professor of Biblical Exegesis, University of Manchester), and Dr. J. Strong (Chairman and Professor of Education, University of Leeds).

${ }^{10}$ The Advisory Council for Christian Education Overseas was a sub-committee of the International Missionary Council which had been established in 1921 having emerged from the 1910 Edinburgh World Missionary Conference. The 1928 conference of the International Missionary Council in Jerusalem had been particularly concerned with the need for educational evangelism to enable a common Christianity to become the foundation for world unity and brotherhood. See Bates (1976: 101-3).

${ }^{11}$ Conference on Christian Education at Home and Overseas, April 1931, conference paper VII. Archives of the Christian Education Movement (CEM), Z1, file e., (Advisory Council of Christian Education). University of Birmingham.

${ }^{12}$ Archives of the CEM, Z1, file b., Papers of Tissington Tatlow.

${ }^{13}$ Archives of the CEM, Z1, file d., Resolutions passed at the Swanwick Conference, 1931.

${ }^{14}$ Ibid.

${ }^{15}$ Archives of the CEM, Z1, file d., Minutes of the Continuation Committee, $15^{\text {th }}$ May 1931.

${ }^{16}$ Archives of the CEM, Z1, file d., The Christian Education Group (Provisional).

${ }^{17}$ William Temple (President), Walter Moberly, L. W. Grensted, Arthur Mayhew, William Paton, John

Macmurray, Theodora Day, Dorothy Brock, W. W. Vaughan, H. G. Wood, Spencer Leeson, M. L. Jacks, and a Miss Fairfield.

${ }^{18}$ Archives of the CEM, Z1, file d., The Christian Education Group (Provisional).

${ }^{19}$ Archives of the CEM, Z1, file d., Minutes of the Continuation Committee, $15^{\text {th }}$ May 1931.

${ }^{20}$ Archives of the CEM, Z1, file d., Minutes of the Continuation Committee, $15^{\text {th }}$ May 1931.

${ }^{21}$ Archives of the CEM, Z1, file d., Minutes of the Continuation Committee, $2^{\text {nd }}$ October 1931.

${ }^{22}$ Archives of the CEM, Z1, file d., Minutes of the Continuation Committee, 30 ${ }^{\text {th }}$ October 1931.

${ }^{23}$ Archives of the CEM, Z1, file a., Minutes of the First General Meeting of the ATRK, $5^{\text {th }}$ January 1932.

${ }^{24}$ Archives of the CEM, Z1, file a., letter from Tissington Tatlow to Miss E. Addison Phillips (Chairman of the ATRK), $29^{\text {th }}$ September 1935.

${ }^{25}$ Archives of the Christian Education Movement (CEM), Z1, Box C, Minutes of the Christian Education Group, $28^{\text {th }}$ December, 1932.

${ }^{26}$ Education Act, 1944, 7 \& 8 GEO, 6, chapter 31, section 25[1-2].

${ }^{27}$ Ibid., Fifth Schedule.

${ }^{28}$ Ibid., section 26.

${ }^{29}$ Ibid., section 29[2].

${ }^{30}$ CEM Archive, Z8 journal material, the sixty-fifth meeting of the Editorial Board of Religion in Education, $27^{\text {th }}$ February 1957.

${ }^{31}$ CEM Archive, Z8 journal material, the seventy-second meeting of the Editorial Board of Religion in Education, $8^{\text {th }}$ June 1959.

${ }^{32}$ CEM Archive, Z8, journal material, 1959.

${ }^{33}$ CEM Archive, Z8, journal material, 1959, Religion in Education: notes on policy questions, July 1959.

${ }^{34}$ CEM Archive, Z10, SCM correspondence journal, letter from David Edwards to Francis Venables, $20^{\text {th }}$ February 1961.

${ }^{35}$ CEM Archive, Z10, SCM correspondence journal, Harold Loukes to David Edwards, $20^{\text {th }}$ February 1961

${ }^{36}$ CEM Archive, Z10, SCM correspondence journal, Francis Venables to David Edwards, $5^{\text {th }}$ May 1961 and Venables to Edwards, $19^{\text {th }}$ May 1961

${ }^{37}$ CEM Archive, Q56, Correspondent [Tim Newell-Price?] to the Bishop of London, $5^{\text {th }}$ June 1963.

${ }^{38}$ CEM Archive, Q56, Correspondent to the Bishop of London, $5^{\text {th }}$ June 1963.

${ }^{39}$ Ibid.

${ }^{40}$ Ibid.

${ }^{41}$ Ibid.

${ }^{42}$ CEM Archive, Q64, Correspondence between Philip Lee-Woolf and a Thomas Goodman, 31 ${ }^{\text {st }}$ January 1967.

${ }^{43}$ CEM Archive, Q29, National Association for Teachers of Religious Knowledge, invitation letter to an event at Birmingham Town Hall, February 1968.

${ }^{44}$ CEM Archive, Q29, NATORK information leaflet.

${ }^{45}$ CEM Archive, Q29, T. S. Phillimore (General Secretary of the Birmingham Council of Christian Education) to Philip Lee-Woolf, $1^{\text {st }}$ April 1968.

${ }^{46}$ CEM Archive, Q29, Philip Lee-Woolf to Richard O’Brien, 8 ${ }^{\text {th }}$ January 1970. 
${ }^{47}$ CEM Archive, Q29, Philip Lee-Woolf to Eric Baker, $8^{\text {th }}$ December 1967; Philip Lee-Woolf to John Marsh, $13^{\text {th }}$ December 1967; Philip Lee-Woolf to John Hull, $11^{\text {th }}$ March 1968; Philip Lee-Woolf to a member, $3^{\text {rd }}$ April 1968.

${ }^{48}$ CEM Archive, Q29, Philip Lee-Woolf to John Marsh, $13^{\text {th }}$ December 1967. Authors' emphasis.

${ }^{49}$ CEM Archive, Q29, Philip Lee-Woolf to Richard O’Brien, $8^{\text {th }}$ January 1970.

${ }^{50}$ CEM Archive, Q36, National Teachers’ Committee Secretary, R.H. Shepard, 7 July 1972.

${ }^{51}$ CEM Archive, Q64, Correspondence between Mark Hammer and Philip Lee-Woolf, $21^{\text {st }}$ May 1970.

${ }^{52}$ CEM Archive, Q64, Letter to John Hull, editor of Learning for Living (correspondent anonymized), $13^{\text {th }}$ July 1977 (referring to the summer 1977 editorial of Learning for Living).

${ }^{53}$ CEM Archive, Q64, Letter from Edward Robinson to John Hull, $16^{\text {th }}$ February 1978. 